No. $2006 / 14$

\title{
Portfolio Inertia and Stock Market Fluctuations
}

Yannis Bilias, Dimitris Georgarakos, and Michael Haliassos 


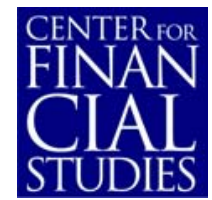

\section{Center for Financial Studies}

The Center for Financial Studies is a nonprofit research organization, supported by an association of more than 120 banks, insurance companies, industrial corporations and public institutions. Established in 1968 and closely affiliated with the University of Frankfurt, it provides a strong link between the financial community and academia.

The CFS Working Paper Series presents the result of scientific research on selected topics in the field of money, banking and finance. The authors were either participants in the Center's Research Fellow Program or members of one of the Center's Research Projects.

If you would like to know more about the Center for Financial Studies, please let us know of your interest.

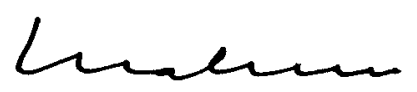

Prof. Dr. Jan Pieter Krahnen

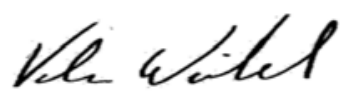

Prof. Volker Wieland, Ph.D. 


\title{
CFS Working Paper No. 2006/14
}

\section{Portfolio Inertia and Stock Market Fluctuations*}

\author{
Yanis Bilias ${ }^{1}$, Dimitris Georgarakos ${ }^{2}$, \\ and Michael Haliassos ${ }^{3}$
}

This Version: June 1, 2006

First Draft: June 2005

\begin{abstract}
:
Several recent studies have addressed household participation in the stock market, but relatively few have focused on household stock trading behavior. Household trading is important for the stock market, as households own more than $40 \%$ of the NYSE capitalization directly and can also influence trading patterns of institutional investors by adjusting their indirect stock holdings. Existing studies based on administrative data offer conflicting results. Discount brokerage data show excessive trading to the detriment of stockholders, while data on retirement accounts indicate extreme inactivity. This paper uses data representative of the population to document the extent of household portfolio inertia and to link it to household characteristics and to stock market movements. We document considerable portfolio inertia, as regards both changing stockholding participation status and trading stocks, and find that specific household characteristics contribute to the tendency to exhibit such inertia. Although our findings suggest some dependence of trading directly-held equity through brokerage accounts on the performance of the stock market index, they do not indicate that the recent expansion in the stockholder base and the experience of the stock market downswing have significantly altered the overall propensity of households to trade in stocks or to switch participation status in a way that could contribute to stock market instability.
\end{abstract}

JEL Classification: G110, E210

Keywords: Stockholding, Portfolio Inertia, Stock Trading, Household Portfolios

\footnotetext{
* We thank Martin Browning, Chris Carroll, Dimitris Christelis, Arie Kapteyn, Deborah Lucas, Donna Nordquist, Victor Rios Rull, Tullio Jappelli, and especially James Smith, Nick Souleles, and Luis Viceira for very helpful suggestions. We thank participants in the 2005 NBER Summer Institute (Group on Capital Markets), the 2005 CAM conference in Copenhagen, and the XIII Conference of the Spanish Finance Association, as well as seminar participants at the ECB, Bundesbank, and the University of Piraeus for helpful comments. This work has been supported in part by the European Community's Human Potential Program under contract HPRN-CT-2002-00235, [AGE], and by the Center for Financial Studies (CFS) under the Research Program 'Household Wealth Management'.

University of Cyprus and Center for Financial Studies; email: bilias@ucy.ac.cy

2 University of Frankfurt and Center for Financial Studies; email: georgarakos@wiwi.uni-frankfurt.de

3 University of Frankfurt, Center for Studies and MEA; email: haliassos@wiwi.uni-frankfurt.de
} 


\section{Introduction}

The spread of equity culture, namely the increase in the percentage of households participating in stockholding over the past twenty years, has now been extensively documented, both for the US and for major European countries (see Campbell, 2006; and the contributions in Guiso, Haliassos, and Jappelli, 2001). Much less well understood are the stock trading behavior of households, the frequency with which they tend to move in and out of the stock market, and whether these have changed over time. Yet these issues are quite important, as households own about $40 \%$ of the NYSE capitalization directly, and may additionally influence trading by institutional investors when they adjust their indirect stock holdings in mutual funds or retirement accounts.

Recent theoretical models of household portfolio choice with background income risk imply that households should adjust their stockholding participation status or portfolio shares of risky assets in response to a variety of changes. These are either specific to the household - such as changes in wealth, income or age - or features of the market environment - such as expected returns or return volatility (see Campbell and Viceira, 2002; Haliassos and Michaelides, 2003; Cocco, Gomes, Maenhout, 2005; Gomes and Michaelides, 2005)..

Although the existing empirical literature on stock trading by households is not extensive (see section 2 below), it already points to substantial heterogeneity in the frequency with which households trade stocks. There is stark contrast between administrative data on households with discount brokerage accounts and administrative data from retirement plans. The former imply overtrading to the households' detriment, while the latter show widespread inactivity of households over periods of time as long as ten years. This sharp contrast makes it all the more 
important to understand what drives trading differences in the household population at large, and whether and how trading frequency and entry and exit are influenced by household characteristics and by stock market conditions.

Understanding frequencies of trading and of stock market entry and exit is particularly relevant in the face of changes in the composition of the stockholder pool, induced by the spread of equity culture since the early 1990s. An important lesson from the empirical literature on stock market participation is that certain household characteristics, such as high educational attainment or sizeable wealth or income, contribute to stock market participation, probably by allowing households to overcome fixed costs of entry into the market. It is then natural to expect that the spread of equity culture is likely to be associated with progressive entry of 'marginal' investors into the stockholder pool, with lower levels of education and more limited resources. This creates, in turn, concerns about stockholding levels likely to be chosen (or achieved) by a so-transformed stockholding pool, as well as about its trading practices and possible overreaction to market swings that could contribute to stock market volatility (see, for example, Guiso et al., 2003).

Using cross-sectional data from the Survey of Consumer Finances and new methods to construct counterfactual distributions, Bilias, Georgarakos and Haliassos (2006) provide empirical evidence that this simple view of the evolution of the stockholder base may be unwarranted. The evidence suggests strongly that the stock market upswing of the 1990s did attract sizeable numbers of marginal stockholders, resulting in smaller stockholding levels across the distribution of holdings. However, entry and exit during the period immediately following the downswing are estimated to have resulted in a stockholder pool conducive to larger stockholding levels, presumably by discouraging marginal stockholders and attracting others whose 
characteristics, attitudes, and financial practices favored larger holdings. The underlying idea that household portfolio behavior is not free of investment mistakes and that these mistakes are disproportionately present among particular demographic groups is consistent with a number of recent papers. ${ }^{1}$

This paper deals with stock market entry and exit and the frequency of trading by households, in the face of considerable spread of equity culture and of substantial stock market movements during the past two decades. It investigates whether we actually see marked changes in the incidence of entry and exit or in trading frequencies and patterns, as new stockholders are brought into the market and as the stock market swings up or down. It explores the role of household characteristics and of the stock market index in determining entry, exit, frequency, and direction of trading. The paper uses both panel data (from the Panel Study of Income Dynamics PSID - using mainly the waves between 1994 and 2003 but sometimes going as far back as 1984); and a time series of cross sections (from the Survey of Consumer Finances - SCF - between 1989 and 2004). Various types of stockholding are considered, as available in the data (direct, through mutual funds, and through retirement accounts). As we are using data representative of the US population, we provide a reconciliation of overtrading results found in discount broker data with inertia results found in other administrative data. The upshot of the paper is that, while households with brokerage accounts do exhibit great incidence and frequency of trading as well as sensitivity to stock market movements, the bulk of the population exhibits considerable inertia, both in terms of trading and in terms of changing participation status. We do not find evidence of a change in this degree of inertia across the stock market upswing and downswing or as stock market participation grew. 
Section 2 of the paper surveys recent literature on stock trading by households.

Section 3 discusses the theoretical background to the issue of portfolio inertia in stockholding. Section 4 describes the data. Section 5 presents results from the PSID regarding participation inertia, combining all types of stockholding. Section 6 discusses inertia in trading and trading practices regarding directly held stock and mutual funds. Section 7 reports findings on trading directly held stocks through brokerage accounts, based on the SCF. Section 8 offers concluding remarks.

\section{Existing Literature}

Most of the existing literature on stock trading by households has focused on administrative data sets, with only a few studies using surveys representative of the US population. Even within studies using administrative data, there is a stark contrast between studies that document excessive trading and others that document considerable inactivity on the part of households.

Barber and Odean (2000) study households with accounts at a large US discount broker, who provides trading services for common stocks without financial advice, during the period 1991 to 1996 . They show that such households tend to engage in excessive stock trading, arguably because of overconfidence, and that this results in net stock portfolio returns substantially below the market, mainly because it causes them to pay enormous transactions costs. The average household in their sample turns over 75 percent of its portfolio annually. They aptly summarize their findings as showing that 'trading is hazardous to your wealth'. Barber and Odean (2001) document that men trade 45 percent more than women and earn annual riskadjusted net returns that are 1.4 percent less than those earned by women. ${ }^{2}$ Ivković, Poterba and Weisbenner (2004) use the same data set and distinguish between trading 
on taxable and tax-deferred accounts. They find differences in trading patterns that are consistent with expected effects of capital gains taxation.

While researchers using discount broker accounts and general stock market registers wonder why there is so much trading, those who focus on individual retirement accounts find a great degree of portfolio inactivity. The literature on retirement accounts, based on various administrative data sets, points to a pronounced tendency of most participants to be passive and do nothing, or what Samuelson and Zeckhauser (1988) called 'status quo bias in decision making'. Ameriks and Zeldes (2004) use panel quarterly data on (tax-deferred) retirement account balances and contributions held by TIAA-CREF, with participants drawn mainly from faculty and other full-time employees at US institutions of higher education and research. Although their main focus is on estimating age effects on portfolio composition, they also report evidence on trading inertia. They find that over a ten-year period (19871996), close to 50 percent of their sample made no changes to the share of stocks in either their retirement accumulation or in their flow contributions, despite the negligible cost of making such changes. ${ }^{3}$

Agnew, Balduzzi, and Sunden (2004) follow a panel of nearly seven thousand 401(k) retirement accounts from April 1994 to August 1998 and find very limited portfolio reshuffling, in sharp contrast to existing evidence from discount brokerage accounts. Over $87 \%$ observations of annual number of trades in their panel are zero, and only $7 \%$ of the observations exceed one.

Huberman and Sengmueller (2004) study the dynamics of investment in company stock within $401(\mathrm{k})$ plans, by employees working in that company. Using aggregate (plan-level) data, constructed from SEC filings, on a panel of 153 plans over at most eight years (1991-98), they study the determinants of transfers in and out 
of the company stock as a fraction of all assets in the plan, and the fraction of new savings invested in company stock. They find that good past returns attract more investments, but bad past returns do not cause reduction in plan holdings of company stock. ${ }^{4}$ As their data are aggregate and contain no information on participant characteristics, they do not study the role of variation in individual attributes. They do stress, however, that participants in defined contribution plans make very few active changes to their portfolios, and that the effects they find are due to the action of the minority of alert participants.

Administrative data sets have certain advantages and disadvantages relative to survey data. On the positive side, administrative data sets tend to be less subject to measurement error and reporting biases than survey data. They track closely the same accounts over extended periods of time, providing exact information on the frequency of trading and on the size of trades. They also make it possible to estimate accountspecific rates of portfolio returns and to analyze performance of individual investors relative to the market, and trades in response to past own performance.

On the negative side, they tend to involve selected samples, as the authors recognize. For example, those with a discount broker account are most likely to be households that want to trade in the stock market and feel confident that they can do so without advice from the brokerage firm (hence their use of discount rather than retail brokers); TIAA-CREF participants are drawn from a specific sector and tend to be more highly educated than the general population, and so on. Secondly, since only accounts are tracked, these data sets are good for analyzing trading behavior but less appropriate for analyzing entry and exit into the stock market. Third, they give a partial view of stockholding behavior, as they only focus on one aspect of stockholding, be it direct holding of common stocks or holding of retirement 
accounts, with specific liquidity characteristics and costs of rebalancing. For example, infrequent trading on retirement accounts may simply be the result of unwillingness of households to alter their retirement planning, while they would be willing to reshuffle the rest of their portfolio; or it may be a sign of extreme portfolio inertia, given that reallocations of accumulations in, or flow contributions to retirement accounts are nearly costless. Finally, administrative data sets typically contain small amounts of information regarding household demographics and the overall household portfolio, and they do not allow study of the influence of such household characteristics on portfolio inertia.

To our knowledge, there is little previous work on active trading of stocks using survey data representative of the population, and it has a different focus. In an early paper, Souleles (1999) studies determinants of the size of securities purchases, combining data from the CEX and from the Michigan consumer sentiment surveys. He finds that household-specific hedging motives have independent predictive power for the size of securities purchases above and beyond the information in returns, with marginal effects estimated to be bigger than those of returns. Given the short panel dimension of the CEX, where each household is surveyed four times but only for one year in total, and the use of two complementary data sources for the same regressions, Souleles had to rely on extensive imputations for some of the key explanatory variables in his regressions.

Guskova, Juster, and Stafford (2004) use PSID data from 1994 and 1999 and compare the relevance of wealth and income for stock market participation in the two years, in order to provide a test of simple cost-based explanations for participation. They find an increased role for income and wealth variables in 1999, and evidence that lower mortgage payments contributed to purchasing stocks during that period. 
In a very recent paper, Brunnermeier and Nagel (2005) study the issue of whether wealth fluctuations induce changes in risk aversion, by looking at portfolio shares conditional on participation, and using survey data from PSID and CEX. They find that wealth shocks do not induce households to increase their portfolio share in risky assets, conditional on participation in risky assets, but that capital gains and losses do have an impact, with capital gains continuing to affect portfolio shares even after five years. In addition to delivering the authors' main point against time-varying risk aversion, both findings are consistent with inertia in trading stocks, conditional on participation, and they nicely complement our findings on participation and trading inertia across the population of stockholders and non-stockholders.

\section{Theoretical Background}

There is no general theory of what determines stock trading behavior. Implications of theoretical models range from no trading at all ${ }^{5}$ (Milgrom and Stokey, 1982) to trading up to the point of equating the marginal benefit of trading to the marginal cost of doing so (Grossman and Stiglitz, 1980), to models of overconfidence where investors trade to their detriment (e.g., Odean, 1998). In this section, we briefly discuss theoretical insights to determinants of entry and exit and of stock trading by households derived from the body of recent literature on household portfolio choice in the face of background, non-asset income risk. ${ }^{6}$

Fixed entry costs are probably the dominant explanation of limited participation in the stock market in existing literature, and thus a key component of understanding what limits entry into the stock market. ${ }^{7}$ Factors that reduce the amount of stockholding that the household would undertake if it gained access to the stock market also serve to reduce the probability that it would decide to pay any given fixed 
cost to switch participation status from non-stockholder to stockholder. Similarly, factors that raise the size of fixed entry costs faced by a household for given demand for stocks, work in the same direction.

Theory leads us to expect positive roles of wealth and of non-asset income on the probability of entry, mainly because of the positive effect of cash on hand on stock demand. The role of educational attainment is more involved. Higher educational attainment tends to be associated empirically with steeper age-earnings profiles and with lower variances of shocks to labor income. ${ }^{8}$ This alone would make more educated households less likely to save (to provide for the future and for shocks to income), but this factor can be offset by lower costs faced by the more educated in gathering and processing information relative to stockholding. Empirical participation studies usually find that higher education contributes to stockholding participation.

Poor health increases the costs of processing information, may be associated with committed expenditures on health care, and may raise the perceived risk of future health expenditures. While higher precautionary wealth demand could boost stock demand, it seems likely that higher participation costs and committed expenditures among people of poor health would discourage entry in the stock market.

Retirement implies dependence on accumulated assets rather than on human wealth for financing consumption, more limited opportunities for time diversification of bad shocks (see Gollier, 2001), and more limited possibilities for alleviating such shocks through borrowing and varying labor supply. All these factors would make likely a negative effect on the likelihood of entering the stock market. Finally, empirical participation studies imply that belonging to a minority reduces the probability of participation. This is usually interpreted as reflecting more limited 
targeting of minorities by the financial sector, which would in turn suggest that minorities are less likely to switch into stockholding, controlling for other factors.

Exits from the stock market (i.e. switches from participation to nonparticipation status) are more involved, yet present in the data, as we shall see below. ${ }^{9}$ Models with borrowing constraints in the form of no-short-sales restrictions on stocks and on the riskless asset imply that a drop in current cash on hand (relative to the permanent component of non-asset income) can push a household into the region of binding borrowing constraints, where the desire to borrow is so pronounced that no stockholding takes place. In these models, this induces an exit from stockholding.

Exit from stockholding could be generated for a broader class of households by the presence of recurring participation costs. Factors that generate low demand for stocks (e.g., low resources, aging, retirement) can prompt households to exit when their desired exposure to stocks is not big enough to justify paying the recurring cost of participation. Such tendency to exit would be tempered by having to face re-entry costs that are high relative to continuing participation costs, as well as by any trading fees (such as commissions and bid-ask spreads).

Exits should also depend on accumulated capital gains or losses of the household in tax systems where gains are taxed at realization, or when behavioral finance considerations such as the 'disposition effect' of Shefrin and Statman (1985) are important. Capital gains taxation tends to contribute to a lock-in effect, i.e. a reduced tendency of investors to sell appreciated stock, so as to avoid paying the associated capital gains tax, and an increased tendency to sell depreciated stock. The disposition effect works in the opposite direction. It is associated with investor unwillingness to admit failure and to dispose of assets that have declined in value; and 
with investor willingness to sell appreciated assets, lest capital gains turn into capital losses.

Let us now turn to the probability of trading. For households that do not currently hold stocks, a decision to actively enter the stock market should imply a decision to purchase (trade) stocks. So, the factors that we have identified as playing a role in entry should apply also to inducing purchases by current non-stockholders. For current stockholders, a decision to buy stocks should result from factors that raise the demand for stocks relative to current holdings, such as an increase in cash on hand, an improvement in the perceived equity premium, a reduction in perceived stock market volatility, improved consumer confidence and expectations regarding future incomes, or an improved health condition. Good performance of the market could also induce purchases, if it leads to expectations of better future performance, rationally or irrationally. 'Return chasing' behavior would fall under this category.

To a first approximation, decisions to sell stocks should arise symmetrically. Departures from this symmetry could be induced by tax considerations, such as capital gains taxation at realization, or by behavioral factors such as the disposition effect favoring trades in one direction rather than the other. 'Overconfidence', stressed in the work of Barber and Odean, would encourage excessive trading in both directions, lowering realized returns net of transactions costs.

There is no reason to expect that the same patterns of participation and trading inertia should be observed across all types of stockholding, from direct stockholding, to mutual funds, to stockholding in retirement accounts. Trading costs are not in general the same across these stockholding locations, tax implications of trades are not the same, and investor willingness to trade need not be the same across different types of stockholding. For example, retirement accounts often allow costless changes 
in allocations or in the composition of new flows (e.g., via the internet) and do not entail tax consequences: stocks can be exchanged for the riskless fund without tax consequences, even when they have incurred capital gains. At the opposite end of the spectrum, trades of directly held stocks may be costly, both in terms of commissions and bid-ask spreads but also in terms of their consequences for capital gains taxes. Even for given costs and tax considerations, households may have lower willingness to engage in speculative trading of their retirement accumulations compared to mutual funds and directly held stocks. ${ }^{10}$

\section{The Data}

In this paper, we use panel data from various waves of the PSID, a longitudinal survey that offers a broad set of information on a representative sample of US individuals and their families; and repeated cross sections from the SCF, which is not subject to top coding and includes even more detailed information on portfolios. The PSID has been interviewing households on an annual basis between 1968 and 1996. Since 1996, interviews are contacted biennially. In this paper, we employ data from 1984, 1989, 1994, 1999 and 2001, i.e. the survey years that provide detailed information on various household wealth components. We also make use of recently released data from 2003.

In all of our analysis, we study families that experienced no change in their head. Up to and including the 1994 interview, households were asked whether they owned any shares of stocks in publicly held corporations, mutual funds, or investment trusts - including stocks in employer-based pensions or IRAs. From 1999 onwards, there is a separate question regarding ownership of IRAs, as well as information on whether IRAs are mostly invested in stocks, interest earning assets, or split between 
the two. Based on the latter responses, we allocate $75 \%, 25 \%$ and $50 \%$ of the value of IRA to stocks, respectively.

In our regression analysis, we control separately for net financial and net real wealth, to allow for differential effects of wealth components that differ in liquidity. Net financial wealth comprises the total amount held in liquid assets (checking and savings accounts, money market funds, certificates of deposits, savings bonds, or treasury bills), money in private annuities and IRAs, bonds, cash value in a life insurance policy and other assets (a valuable collection for investment purposes, rights in a trust or estate), stocks (shares of stock in publicly held corporations, mutual funds, investment trusts), minus other debts (such as credit cards, student loans, medical or legal bills, or loans from relatives). ${ }^{11}$ Net real wealth is derived as the sum of home equity (value of the home minus remaining mortgage principal), equity in other real estate, equity in a farm or business plus equity in vehicles. ${ }^{12}$

In each interview households were asked about transactions they made in stocks since the last survey year with a wealth supplement (e.g. in 1999 survey for the time from 1994 to 1999). They were asked to give details on whether they purchased or sold stocks and the amounts they put in or took out of stocks. Information regarding the within-interval frequency of such trading is not available.

Up to 1994 this series of questions refers to transaction in stocks generally, including those invested in IRAs. From 1999 onwards respondents were asked about transactions in non-IRA stocks. Hence, in post-1994 surveys, information on stock transactions in publicly held corporations, mutual funds, or investment trusts, including any automatic reinvestments - but not including any IRAs, is available. We mainly look at such transactions that took place between 1994 and 1999 and between 1999 and 2003. The analysis for the latter period is feasible after combining the 
relevant information from 1999-2001 and 2001-2003 sub-periods. We also look at transactions prior to 1994 , however these refer to a broader definition that takes also into account IRA stocks.

We also employ data from the 1989, 1992, 1995, 1998, 2001 and 2004 Surveys of Consumer Finances (see Appendix B for description of variables). Compared to PSID, they are not subject to top coding, and they provide a detailed wealth breakdown and useful information on households' financial attitudes and practices. Nevertheless, the SCF does not track the same unit over time. Households are asked first whether they hold a brokerage account for the purchase or sale of stocks and other securities. Households with brokerage accounts are then asked how many times they bought or sold stocks through a broker during the last year, allowing a comparison of trading practices with the general population.

\section{Stock Market Entry and Exit}

\subsection{Maintaining Participation Status}

We first look at inertia in participation, namely the tendency to have the same participation status in stockholding at the end of the sample period as at the beginning. Both conceptually and in practice, participation inertia is distinct from trading inertia. In principle, changing stockholding participation status does not require a household to trade. For example, receiving stocks as a part of bequests or transferring stocks to children as a gift during a household's life would induce such changes in participation status without registering trades.

In the data, PSID responses to trading questions do not always match up with responses to questions on stockholding participation. Some of these may reflect stock transfers without trades, some may arise purely from survey collection practices, ${ }^{13}$ 
while others may be due to recall bias (see also Vissing Jorgensen, 2002), but it is impossible to tell what is the reason for the mismatch and which of the two responses (on ownership or on trading) is inaccurate. Our choice to analyze first participation and then trading patterns allows us not to throw away these observations, most of which are likely to represent legitimate statements about at least one of these two types of inertia.

Tables $1 \mathrm{a}$ and $1 \mathrm{~b}$ present a breakdown of households according to their combination of participation status at the endpoints of periods 1994-1999 and 19992003, using 1999 sample weights for both panels. This shows a tendency of the vast majority of households to exhibit the same participation status over time. Comparing 1994 to 1999 (Table 1a), we see that about three quarters of the sample were in the same participation status at the end of the period as at the beginning, with slightly more than forty percent remaining non-participants. About 8 percent were stockholders at the beginning of the period but not at the end, while 18 percent had moved in the opposite direction.

Comparing the peak of the stock market, 1999, to 2003 after the downfall (Table 1b), we find that just under 80 percent of households were exhibiting the same participation status at the beginning and at the end of the period, which is even larger than during the period of the stock market upswing. The remaining 20 percent switched status, with slightly more switching into stockownership, despite the intervening market downfall. ${ }^{14}$ Of course, looking only at end points does not necessarily imply that households did not trade within the period. This is an issue which we will examine later in the paper. 


\subsection{Determinants of Conditional Participation Probabilities}

In this section, we ask which factors tend to influence entry and exit across two periods of interest: the period encompassing the substantial stock market expansion, 1994 to 1999, and the one encompassing the major market downfall, 1999 to 2003. We consider ownership in directly held stocks, in mutual funds, in investment trusts, and in employer-based pensions and IRAs.

For each period, we estimate a bivariate probit, allowing unobserved heterogeneity to influence participation decisions at both interval end points, and each observable factor to have potentially different effects at each end point. Indeed, we find positive correlation between unobserved factors influencing participation at the beginning and at the end of the period. We consider balanced samples across two nodes at a time, but we do not require households to be present in all three years 1994, 1999, and 2003. Households with zero wealth at both end points of an interval are excluded from estimation, so as not to equate stock market non-participation with the decision to hold no assets at all (or the inability to do so).

Tables 2 and 3 present marginal effects from bivariate probit regressions regarding ownership decisions at the beginning and at the end of the two periods: 1994-1999, and 1999-2003. In this paper, we try to avoid some pitfalls involved in automatic computation of marginal effects by standard econometric software, which have recently been emphasized. We explain how we overcome these problems in Appendix A. We find that typical results of static participation studies convey to bivariate probits across two periods. We do not find pronounced age effects on participation, except for a negative effect of being young. Having more children discourages stock market participation. This is likely to be due to the current cost and projected future committed expenditures on children, which seem to dominate the 
incentive to take advantage of the wealth-building potential of the equity premium and any motives to bequeath capital gains assets.

Belonging to a minority strongly discourages stockholding participation, and this is true in all years under consideration. We do find that poor health discourages participation, but the finding is not consistently present across all years and periods. We confirm the strong positive role of education on participation found in many other participation studies. The level of resources, whether in the form of income, net financial wealth, or net real wealth also encourages participation. Controlling for current resources, stock market participation is further encouraged by having received an inheritance within the past 5 years. By contrast, we do not find any effect on participation of having moved during the period.

Figure 1 plots predicted conditional probabilities of participation, estimated using the bivariate probit estimates, for households that find themselves at the $25^{\text {th }}$, the $50^{\text {th }}$, or the $75^{\text {th }}$ percentile of each of the distributions of income, net financial wealth, and net real wealth, and who have their remaining characteristics set equal to the respective weighted sample medians. We know from the participation literature that the unconditional probability of participation (non-participation) is increasing (decreasing) in the level of household resources and in the position of the household in the distribution of resources. Figure 1 shows that analogous results hold also for the conditional probabilities of participation and non-participation, whether we condition on beginning-of-period participation or non-participation. Probabilities of participation (non-participation), conditional on beginning-of-period participation (non-participation), decrease (increase) with the position of the household in the distribution of resources (income, non-stock financial wealth, and real wealth). 
Participation inertia is evident in Figure 1. Conditional on any participation status at the beginning of the period, the probability of exhibiting the same status at the end of the period is greater than the probability of exhibiting a changed status. Estimated probabilities of stock market participation at the end of the period, conditional on participation at the beginning of the period, are not very dissimilar across the stock market expansion and contraction, suggesting that they are not particularly sensitive to the stock market environment. We find more sizeable differences in the probability of non-participation at the end of the period, conditional on zero stockholding at the beginning. Conditional probabilities of staying out of the market are higher following the stock market downturn than over the boom, for all resource percentiles considered. These results suggest that the stock market downturn has mainly discouraged non-participants from entering rather than encouraging a mass exodus from the stock market.

Figure 2 plots the same estimated conditional probabilities, now varying the educational attainment of the household head. These confirm the presence of participation inertia for households with high school education or below. They show, however, that a college degree contributes to overcoming inertia in terms of staying out of the market. Controlling for all other characteristics (set at the median level), college graduates are actually more likely to switch into ownership than to remain non-participants, both before and after the stock market downswing. Regardless of education, the household that is median in terms of other characteristics has higher probability to stay out of the market after the downswing than during the upswing. Conditional probabilities of exiting are quite similar before and after the downswing, with high school graduates exhibiting some increase in their exit probability, controlling for other characteristics. 
Table 4.1 presents results on the role of further factors in a different, more compact way. We compute marginal effects, interpreted as effects on the estimated probability of having exited from the stock market by the end of the period, conditional on being a participant at the start of the period. This computation provides answers to the important question of which characteristics contributed to stock market exits during the upswing and following the downswing, and by how much.

Controlling for other characteristics, white non-hispanic households are less likely to exit, conditional on owning at the beginning of the period. The effect is large in both periods, but even larger in the bad times. Poor health does not influence the conditional probability of exit during the upswing, but it does raise it during the downswing by about 6 percentage points. Lower household resources, whether in the form of income, non-stock net financial wealth, or net real wealth, significantly encourage exit from the stock market, both in good and in bad times. The marginal effect is larger in bad times, especially for income but also for net financial wealth, though not for net real wealth. Thus, liquid resources seem to matter for staying in the market, controlling for other characteristics, and this result is intuitively appealing.

All in all, our conclusion on entry and exit for all types of stockholding combined is that they are significantly influenced by a number of household characteristics, but they have not changed much across the period of the stock market upswing or downswing. The downswing is more likely to have encouraged staying out, rather than getting out of the market. Nevertheless, it also seems to have strengthened the effects of several factors, including minority status, poor health, and liquid resources, on conditional probabilities of exit from the stock market. 


\section{Trading Incidence and Patterns}

In this Section, we study household trading behavior in periods of different stock market conditions. Using the survey responses in PSID, we classify households into those who undertake no trade in stocks in the period considered, those who only buy stocks, those who only sell stocks, and those who report both buying and selling stocks. In order to be able to compare the periods before and after the stock market downswing, trading here refers to stocks other than stocks in IRA's. This is imposed on us by data limitations, but it provides a nice complement to the work of Ameriks and Zeldes (2004) that focuses on (TIAA-CREF) retirement portfolios.

Although we do not know the actual number of transactions undertaken by households who trade during a given period ${ }^{15}$, it is reasonable to expect that households who report having traded on both sides of the market are on average more active traders than those having traded in only one direction. We do not combine households who report buying only and selling only, so as to be able to distinguish trading against the market from trading with the market.

\subsection{Trading Incidence and Patterns Across Demographic Groups}

In Tables 5a-d, we consider a full balanced panel of households in 1994, 1999, 2001, and 2003, using 1999 sample weights, to trace any changes in their trading incidence and patterns across the stock market upswing and downswing. We consider the period of stock market boom (1994-1999), and the period following the stock market downswing (1999-2003), which are of almost equal length, so that comparisons of rates of inertia between them are meaningful. The period following the burst of the bubble is further broken down into two sub-periods: the immediate aftermath of the downswing (1999-2001), and the subsequent period (2001-2003), by 
which households have had time to process the implications of the downswing and to adjust their portfolios.

As shown in Table 5a, the vast majority of households exhibit complete trade inactivity, with almost three quarters of them not reporting any stock market trade during the five year boom period considered. The proportion of households who report no trade during the subsequent four-year period is only slightly smaller. The substantial drop in the stock market that took place around 2000 was not associated with sizeable increases in the incidence of stock market trading in the population. Looking at the three other columns of Table 5a, we find that the downswing was also not associated with massive increases in the proportion of households who only sold stock, and if anything it was associated with some increase in trading in both directions.

We also break down the period following the downswing into two subperiods, namely 1999-2001 and 2001-2003. Given the smaller length of these periods compared to the original ones, it is not surprising to observe a larger degree of inactivity. We do find evidence of somewhat greater inactivity in the period that is more distant to the stock market downswing of 2000 than in the one immediately following it. Among those who did trade, we find that lower proportions of households undertook any stock purchases (either on their own or in conjunction with stock sales) in the 2001-3 period relative to the 1999-2001 period, and more only sold stocks although they still do not account for more than 3.5 percent of households.

Table $5 \mathrm{~b}$ shows trade inactivity and trading patterns for different groups of educational attainment. These do suggest that inactivity is more limited across more educated groups, but even among college graduates, the majority reports no trade in each of the two longer periods considered, 1994-9 and 1999-2003. Comparing the two 
sub-periods following the downswing, we see that rates of inertia in trade were higher in the second half of the period, at least for those with a high school certificate or more.

Looking at different age groups in Table $5 \mathrm{c}$, we see that inactivity is spread across all ages, but we observe a U-shaped pattern, with inactivity being higher for households with heads below 35 and above 65 years, and somewhat lower in the intermediate age categories. Comparing the upswing to the post-downswing periods, we do not find dramatic changes in proportions of households not trading at all, except perhaps for signs of increased activity among those in the 49-65 age group. Proportions of inactive households have also slightly risen among households 35 years old or younger following the downswing. The U-shaped pattern is preserved when we break down the post-downswing period into 1999-2001 and 2001-2003, with all groups exhibiting somewhat higher inactivity in the latter period.

There are pronounced differences in inactivity across net wealth percentiles, as shown in Table 5d. Households that are higher up in the net wealth distribution (excluding wealth held in stocks) tend to exhibit lower inactivity with respect to stocks compared to those lower in the distribution. While the proportion of households not trading stocks is higher following the downswing than before among the bottom two quartiles of the (non-equity) net wealth distribution, it is lower among the top two quartiles, especially in the top one where the bulk of stockholding is concentrated. Comparing the two sub-periods following the downswing, we find increased inactivity in the second sub-period among all wealth quartiles, with the difference being most pronounced in the richest quartile.

Table 6 takes a more macroscopic view of trading inactivity and stock trading patterns, looking at the entire period from 1984 to $2003 .{ }^{16}$ It should be recalled that 
the asset classes included in the questions on trading were broader up until 1994 and narrower from 1999 on, as explained above. Even with these limitations, Table 6 confirms the impression that overall trading inertia remains more or less at the same levels, with very small increases in the proportion of households trading, despite stock market fluctuations and the spread of equity culture. ${ }^{17}$

\subsection{Determinants of Inactivity and of Trading Practices}

In this Section, we study the role of a number of household characteristics in determining inactivity and trading patterns for stocks not held in IRAs, controlling for remaining characteristics. We run two multinomial logits, one for 1994-99, and the other for 1999-2003. In each case, we divide households into five, mutually exclusive, categories. The first comprises those who do not trade stocks at all during the estimation period and also do not report ownership of stocks in either period. The second represents those who do not trade but report owning stocks in at least one of the two interview years. These distinguish between those who do not trade because they have no involvement with stocks and those who are involved but inactive. With regard to households reporting some trading activity, three other choices are considered: to only buy stocks, to only sell, and to trade in both directions. ${ }^{18}$

Tables 7 and 8 report marginal effects for the presence and type of trading that took place between 1994-1999 and 1999-2003, respectively. ${ }^{19}$ During the upswing, and controlling for other factors, being younger than 50 makes households more likely not to have any involvement in stocks (relative to those between 50 and 65), but if they do, to show some trading activity. Interestingly, age effects on trading activity essentially disappear after the stock market downturn. This suggests that the experience of the downturn may have discouraged young people from trading stocks 
in order to build their portfolios, but we also do not find evidence that they were selling stocks to shift their portfolios towards other assets. Being above 65 does not appear to influence inactivity, either before or after the downturn. This argues against pure horizon effects that should induce households to sell stocks, and is consistent with findings in the literature on conditional portfolio shares that finds no systematic reduction in stock exposure as the household ages. Similarly, entering retirement does not appear to encourage unidirectional sales of stock to finance retirement consumption, nor trade in both directions.

Having more children not only discourages participation in the stock market, but also discourages options that involve purchase of stocks, both before and after the downswing. A larger number of children acts both as a strain on current resources and as committed future expenditures that discourage exposure to stockholding risk. These considerations appear to dominate the motive to exploit the equity premium in order to build up future wealth.

Controlling for other factors, minority households tend to exhibit greater tendency towards inertia in trade, in addition to their known tendency to be less likely to participate, both before and after the stock market downswing. This may be related to more limited targeting of minorities by the financial sector.

We do not find strong health effects on portfolio inactivity or on trading patterns in this quite representative sample of households from all age groups. We do find overall positive effects of education on encouraging trading in any direction, controlling for other factors. Effects are stronger following the downswing: they are uniformly positive and statistically significant at the 5 percent level, whether we refer to high-school education or to college degree. This implies that educated households were more likely to respond to the downswing through active trading. 
Higher income or higher net financial wealth encourages purchases of stocks alone as well as in conjunction with stock sales. Net real wealth has no effect prior to the downswing, but following the downswing it strongly encourages purchases of stock, even combined with sales. The fall in stock prices may have encouraged households with substantial holdings of real equity to trade in stocks, either liquidating some of their real wealth or switching out of less risky assets.

Receipt of inheritance or large gifts often represents a sizeable increase in household resources and one that is in a form not chosen by the household in question but by the person leaving the bequest. Both features could be expected to encourage stock trades. The PSID asks respondents whether they have received inheritance or large gifts in the five-year period preceding the interview. We find that trading responses of households to receipts of inheritance or large gifts are fairly similar but not identical to their responses to other changes in their wealth, and that they seem to be different before and after the stock market downswing. Receipt of inheritance or large gifts, either prior to the beginning of the period or during the period, consistently encourages simultaneous sales and purchases of stock, both before and after the stock market downswing. However, receipt of inheritance or large gifts during the upswing seems to encourage stock purchases, while during the downswing it encourages stock sales. $^{20}$

\section{Trading through Brokerage Accounts}

Given the tension between empirical studies that use administrative data on brokerage accounts and on retirement accounts, we also report results on trading of directly held stocks through brokerage accounts from a data set that is representative of the population, namely the SCF. Such data give us the chance to take into account the 
bias that selected sub-samples usually entail. Furthermore we can take advantage of the more detailed information on all wealth components, demographics and various financial attitudes and practices offered by the SCF. The SCF asks households first whether they have a brokerage account. Those who answer that they do are then asked whether they have traded and how many times they have traded over the year prior to the year of the Survey. We use all available waves of cross-sectional data, from 1989 to 2004.

Table 9 provides a clue to understanding the huge discrepancy in conclusions from existing research based on owners of brokerage accounts and on other segments of the population. The first column reports the percentage of households who hold equity directly during the Survey year. As is well known, this percentage did not vary much during the 1990s, and remains at a high value even following the stock market downswing. The second column shows the percentages of households that report having a brokerage account. This can be either a retail account or a discount brokerage account, and it is thus an overestimate of those who own a discount brokerage account in the population. We see that in all years, less than $20 \%$ of households have a brokerage account. We also observe an increase in these percentages, which resulted in doubling the proportion of brokerage account owners between 1989 and 2001, followed by a decline in 2004 .

The third column shows the percentage of households in the population who bought or sold stocks or other securities through a broker during the year preceding the Survey. While this percentage also nearly doubled during the period under consideration, it remained well below $15 \%$ of the population. However, when expressed as a percentage of brokerage account owners, it shows that between two thirds and three quarters of such owners actually traded in the year preceding each SCF. 
Although relatively few households do own brokerage accounts, the vast majority of owners trade even in the space of a year. This fundamental difference in behavior underlies the very different results obtained to date on the basis of different sets of administrative accounts.

Econometric analysis allows us to probe further into the role that characteristics play in determining ownership of brokerage accounts, and the role characteristics and market conditions play in determining both whether trading through brokerage accounts occurs and how frequent it is. We find that household characteristics have a significant role to play, but so do stock market conditions that were not found to influence the population at large.

We pool data from SCFs between 1989 and 2004 and estimate a two step probit regression, which allows for selection. The first stage models the probability of having a brokerage account, while the second models the probability of having traded through a brokerage account during the year prior to the Survey. Table 10 summarizes the results. The first column refers to marginal effects on the probability of holding a brokerage account and the second displays conditional marginal effects for the incidence of stock trading through a brokerage account during the year prior to the Survey.

In addition to allowing for a number of household characteristics, we include in the first stage a full set of time dummies, while in the second we proxy for stock market performance by including the percentage growth in the S\&P 500 index, deflated by the CPI-U, for the year prior to the Survey. As no single household is a big enough trader to influence the stock price index, these growth rates are truly exogenous to its decision whether to trade or not. These prior-year S\&P real growth rates were positive for all Surveys, except for 1995 and 2001. ${ }^{21}$ Apart from the S\&P real growth rates and a dummy representing years which show a negative rate, we also include in our 
specification an interaction term allowing the coefficient on the real growth rate of the index to differ between periods of upswing and downswing.

Our findings reject the null of zero correlation between unobserved determinants of the two decisions. This implies that we cannot ignore the selection mechanism (probability of owning brokerage accounts) when studying the incidence of trading directly held stocks. We find sizeable marginal effects of the education variables on the probability of owning a brokerage account, with a college graduate being 14 percent more likely to own such an account. Strong positive effects were also obtained with respect to financial control variables, bequest motive, expressed willingness to take above average financial risk, and the number of financial institutions that a household does business with. On the other hand, poor health and children reduce the probability of having a brokerage account. Finally, the time dummies suggest a significant increase in ownership of brokerage accounts throughout the period under consideration.

Turning to the results from the second stage, both growth rate terms exhibit strongly significant conditional marginal effects, implying that stock market performance exerts an important influence on trading of directly held stocks through brokerage accounts. In particular, we find that after controlling for various household characteristics, an assumed 1 p.p. increase in the S\&P real growth rate during stock market expansions and contractions contributes .009 and -.015 respectively to the incidence of trading through a brokerage account. It is worth noting that estimated effects of changes in the index are greater during a contraction rather than an expansion of a given size. ${ }^{22}$ Based on these findings, the incidence of trading directly held stocks, conditional on having a brokerage account, is likely to be greater during downswings, controlling for household characteristics. However, this does not necessarily imply 
stock sales: increased incidence of trades could refer to purchases, sales, or trades in both directions.

Other factors that significantly affect the probability of trading within a year, given brokerage account ownership and controlling for remaining factors, are net financial and net real wealth, being a college graduate, the willingness to take more than average financial risk, and reporting a bequest motive. Bequest motives could contribute to the incidence of trading through brokerage accounts either by simply encouraging purchases to accumulate stocks or by encouraging more active management of stock portfolios. Thus, the discouragement effect on trading that arises from 'step up of basis' provisions for bequeathed capital gains seems to be dominated by other considerations. On the other hand, factors like race, gender, marital status, presence of children, health status and credit constraints, which were significant for brokerage account ownership, no longer affect the incidence of trading among owners of such accounts.

Finally, we go a step further, from modeling the incidence of trading to modeling the frequency of trading. To this end, we estimate a two-step Heckman model where we first model the probability of holding brokerage accounts followed by estimation of the (logarithm) of the number of trades reported within a year. This yields very similar results to those we presented in Table 10 and are not shown for brevity. The effect of growth in the real S\&P 500 index is still present, suggesting a similar pattern to the one we found earlier for the incidence of trading. Gender is now added to the factors reported earlier as having a significant effect on the probability of trading. The role of gender is consistent with the findings of Barber and Odean (2001) for administrative accounts. 
The conclusion from this section is that household characteristics are quite important even for the incidence and frequency of trading directly held stocks through brokerage accounts. The direction of their effects seems broadly similar to that regarding participation and other types of trading inertia. Our results suggest, however, that trading through brokerage accounts tends to be quite sensitive to movements in the stock market index, unlike what is implied by our findings for overall trading inactivity or entry and exit from the market.

\section{Concluding Remarks}

In this paper, we documented the extent and studied the determinants of household portfolio inertia in the face of the spread of equity culture and of considerable stock market index movements, using representative data from various waves of the PSID and SCF. Patterns of household entry and exit from the stock market depend on a number of household characteristics, but are not fundamentally different across the stock market upswing and downswing. The downswing is more likely to have encouraged staying out, rather than getting out of the market. Nevertheless, our findings imply somewhat stronger influences of minority status, poor health, and limited liquid resources on the decision to exit the market during the downswing.

The vast majority of households in the population exhibit complete inactivity in trading stocks (not held in IRAs), across the upswing and downswing of the stock market, and even across the longer period we are able to consider (1984 to 2003). We find no evidence that the proportion of households who only sold stocks increased following the recent downswing, but we observe somewhat greater trading inactivity in the period 2001-2003 compared to 1999-2001. 
We find positive effects of education on discouraging this inactivity, which become stronger following the downswing. Controlling for other characteristics, being young makes households more likely to be buying stocks rather than not trading during the upswing, but such effects disappear after the downswing. Entering retirement does not appear to encourage simple, uni-directional trades to liquidate stocks. Higher income or net financial assets encourage purchases of stocks alone as well as in conjunction with sales throughout the upswing and downswing. Following the downswing, net real wealth becomes significant and encourages purchases of stocks, even combined with sales. Receipt of inheritance or large gifts encourages simultaneous purchases and sales, and it also encourages trading with the market.

Our findings also point to a resolution of the stark contrast between overtrading and inactivity found in existing literature that uses administrative data. Using representative SCF data, we document that only a small number of households own brokerage accounts, but the vast majority of those who do, trade within a year. Econometric analysis suggests that household demographics are quite important both for having a brokerage account and for the incidence and intensity of trading directly held stocks through this account. However, both the incidence and the frequency of trading through brokerage accounts are estimated to be also quite sensitive to movements in the stock market index.

All in all, our findings based on population-wide surveys suggest that a number of household characteristics have systematic effects on incidence of trade and on trading patterns, but trading of directly held stocks and mutual funds among the overall population is both much less prevalent and less sensitive to stock market conditions than trading of directly held stocks among households with brokerage accounts. 


\section{References}

Agnew, Julie, Pierluigi Balduzzi, and Annika Sundén (2004). "Portfolio Choice and Returns in a Large 401(k) Plan", The American Economic Review, forthcoming.

Ameriks, John and Steven Zeldes (2004). "How Do Household Portfolio Shares Vary with Age?" Working Paper.

Barber, Brad M., and Terrance Odean (2000). "Trading Is Hazardous to Your Wealth: The Common Stock Investment Performance of Individual Investors," Journal of Finance, LV, 773-806.

Barber, Brad M. and Terrance Odean, (2001). "Boys will be Boys: Gender, Overconfidence, and Common Stock Investment", Quarterly Journal of Economics, 261-92.

Bartus Tamás (2005). "Estimation of marginal effects using margeff" (2005). The Stata Journal, 5: 309-329.

Bertaut, Carol (1998). "Stockholding Behavior of U.S. Households: Evidence from the 19831989 Survey of Consumer Finances,” Review of Economics and Statistics, 80, 263-75.

Bilias, Yannis, Dimitris Georgarakos, and Michael Haliassos (2006). "Equity Culture and the Distribution of Wealth", working paper.

Brambor Thomas, William Clark and Matt Golder (2005). "Understanding interaction models: Improving Empirical Analysis", Political Analysis, 13: 1-20.

Brunnermeier, M., and S. Nagel, (2005). "Do Wealth Fluctuations Generate Time-Varying Risk Aversion? Micro-Evidence on Individuals' Asset Allocation”, Mimeo.

Calvet, L., J.Y. Campbell, and P. Sodini (2005). "Down or Out: Assessing the Welfare Costs of Household Investment Mistakes”, mimeo.

Campbell, John Y. (2006). "Household Finance”, Forthcoming in Journal of Finance.

Campbell, John Y. and Luis Viceira (2002). Strategic Asset Allocation: Portfolio Choice for Long-term Investors, Oxford: Oxford University Press.

Cocco, J., Gomes, F., Maenhout, P. (2005). "Consumption and portfolio choice over the lifecycle”, Review of Financial Studies, 18, 491-533.

Gollier, Christian (2001). The Economics of Risk and Time, Cambridge, MA: MIT Press.

Graham, J.R., R.H. Campbell, and H. Huang (2005). "Investor Competence, Trading Frequency, and Home Bias”. NBER Working Paper 11426.

Greene William (2000). Econometric Analysis, New York: Macmillan.

Grinblatt, Mark and Matti Keloharju (2001). "What Makes Investors Trade?”, Journal of Finance, LVI, 589-616. 
Grossman, Sanford J., and Joseph E. Stiglitz (1980). "On the Impossibility of Informationally Efficient Markets”, American Economic Review, 70, 393-408.

Gomes, F., and A. Michaelides (2005). "Optimal Life-Cycle Asset Allocation: Understanding the Empirical Evidence”, Journal of Finance, LX, 869-904.

Guiso, Luigi, Michael Haliassos, and Tullio Jappelli (Eds.) (2001). Household Portfolios, Cambridge, MA: MIT Press.

Guiso, Luigi, Michael Haliassos, and Tullio Jappelli (2003). "Household Stockholding in Europe: Where Do We Stand, Where Do We Go?", Economic Policy, 117-64.

Gouskova, Elena, F. Thomas Juster and Frank P. Stafford (2004). "Exploring the Changing Nature of U.S. Stock Market Participation, 1994-1999”, Survey Research Center, University of Michigan Working Paper.

Haliassos, Michael and Carol C. Bertaut (1995)."Why Do So Few Hold Stocks?" The Economic Journal, 105, 1110-29.

Haliassos, Michael and Alexander Michaelides (2003). "Portfolio Choice and Liquidity Constraints", International Economic Review, 44, 143-78.

Heaton, John and Deborah Lucas (2000). "Portfolio Choice in the Presence of Background Risk", The Economic Journal, 110, 1-26.

Huberman, Gur and Paul Sengmuller (2004). "Performance and Employer Stock in 401(k) Plans", Review of Finance, 8, 403-43.

Ivković, Zoran, James Poterba, and Scott Weisbenner (2004). "Tax-Motivated Trading by Individual Investors", MIT working paper.

King Gary, Michael Tomz, and Jason Wittenberg (2003). "Clarify: Software for Interpreting and Presenting Statistical Results", mimeo Harvard University.

Laibson, D., Repetto, A., and J. Tobacman (2003). "A Debt Puzzle”. In Aghion, P., Frydman, R., Stiglitz, J., Woodford, M. (Eds), Knowledge, Information, and Expectations in Modern Economics: In Honor of Edmund S. Phelps, Princeton: Princeton University Press, 228-66.

Lusardi, A., O.S. Mitchell, (2005). "Financial Literacy and Planning: Implications for Retirement Well-Being", mimeo.

Milgrom, Paul, and Nancy Stokey (1982). "Information, Trade, and Common Knowledge", Journal of Economic Theory, 26, 17-27.

Odean, Terrance (1998). "Volume, Volatility, Price, and Profit When All Traders are Above Average", Journal of Finance, 53, 1887-934.

Paiella, Monica (2004). "The Foregone Gains of Incomplete Portfolios”, working paper. 
Polkovnichenko, Valery (2000). "Heterogeneous Labor Income and Preferences: Implications for Stock Market Participation”, mimeo, University of Minnesota.

Rubin, Donald (1987). Multiple Imputation for Nonresponse in Surveys. New York: John Wiley \& Sons.

Samuelson, William and Richard Zeckhauser (1988). "Status Quo Bias in Decision Making", Journal of Risk and Uncertainty, 1, 7-59.

Sirri, E. R. and Tufano, P. (1998) "Costly Search and Mutual Fund Flows", Journal of Finance, 53, 1589-622.

Shefrin, Hersh and Meir Statman (1985). "The Disposition to Sell Winners Too Early and Ride Losers Too Long: Theory and Evidence", Journal of Finance, 40, 777-82.

Souleles, Nicholas (1999). "Household Securities Purchases, Transactions Costs, and Hedging Motives", working paper, Wharton School.

Viceira, Luis (2001). "Optimal Portfolio Choice for Long-Horizon Investors with Nontradable Labor Income”, Journal of Finance, 56, 433-70.

Vissing Jorgensen, Annette (2002). "Towards an Explanation of Household Portfolio Choice Heterogeneity: Nonfinancial Income and Participation Cost Structure", working paper. 


\section{Appendix A: Simulated Average Marginal Effects}

Standard econometric packages automatically report marginal effects for each variable evaluated at mean remaining characteristics. Although it is standard practice to report such automatically generated marginal effects, this is often not economically relevant and sometimes even misleading. For example, it fails to distinguish among single dummy variables and groups of dummy variables that represent a given attribute; or properly evaluate effects of continuous variables entering with particular nonlinear forms; or of variables interacted with other regressors. ${ }^{23}$. Deriving averages of marginal effects that have been first evaluated at each single observation can provide instead a more realistic and economically relevant interpretation.

In this paper, we compute reported marginal effects in the following way. We start by estimating the relevant limited dependent variable model. We then simulate the model parameters (including $\rho$ for models of bivariate probit and probit with selection) by making 1000 independent draws from the multivariate normal distribution, subject to the restrictions that the average of simulated values be equal to the respective estimated parameter and that the structure of the estimated robust variance covariance matrix be preserved. For each such set of simulated parameters, we calculate marginal effects for each individual household and then derive the weighted average marginal effect for the relevant population. We repeat the process for every set of simulated parameters, thus computing a series of average marginal effects. The mean of this series is the estimated marginal effect and the standard error is the simulated standard error of the marginal effect.

In cases of bivariate probit and probit with selection models we distinguish between unconditional and conditional marginal effects, using the formulae described in Green (2000, p.857 \& 860) and calculating the average marginal effects over the full and selected samples, respectively. This allows us to make statements for the population or for a specific group that meets the first stage condition, taking into account correlations in unobserved heterogeneity or correcting for sample selection.

For SCF data, a final point is in order. SCF data have been constructed on the basis of repeated imputation, to eliminate missing values. Five different sets of imputed data are provided. We take into account this feature, by first applying the above procedure to each of the five implicates and then deriving marginal effects and standard errors that are corrected for multiple imputation according to Rubin (1987). 
Appendix B: SCF Data Appendix (Table 10)

non equity net Financial Wealth: Total Financial Assets - publicly traded Stocks Other lines of credit - Credit Card Debt - Installment loans - Other Debt (loans against pensions, loans against life insurance, margin loans, miscellaneous)

net Real Wealth: [1] + [2] + [3] + [4] + [5] - [6] - [7] - [8]

[1] Wealth in Primary Residence: Gross value of primary residence

[2] Other Residential Real Estate (includes land contracts/notes household has made, properties - other than the principal residence - classified under certain codes for family residences, time shares and vacations homes)

[3] Gross equity in Non-residential Real Estate (real estate - other than the principal residence, properties classified under certain codes for family residences, time shares, and vacation homes)

[4] Business Equity (for businesses where the $\mathrm{HH}$ has an active interest, value is net equity if business were sold today, plus loans from $\mathrm{HH}$ to business, minus loans from business to $\mathrm{HH}$ not previously reported, plus value of personal assets used as collateral for business loans that were reported earlier; for businesses where the $\mathrm{HH}$ does not have an active interest, market value of the interest)

[5] Other Wealth: value of vehicles plus other non-financial miscellaneous assets

[6] Principal Residence Debt (mortgage, home equity loans and HELOCs --mopup LOCs divided between HE and other)

[7] Debt for Other Residential Property (includes land contracts, residential property other than the principal residence, misc. vacation, and installment debt reported for cottage/vacation home)

[8] Debt for non-residential real estate mortgages and other loans taken out for investment real estate

Non-investment Income: income from wages, salaries, professional practice or business unemployment compensation, social security, annuity, or other pensions.

Note: All monetary values have been deflated using the CPI-U-Research Series index and expressed into constant 2004 prices.

No high school diploma (omitted variable): Highest grade completed $($ X5901) $<12$ \& No high school diploma or passed equivalent test $(X 5902=5)$ High school graduate: Highest grade completed $(X 5901)<12$ \& Has got high school diploma (X5902=1) or passed equivalent test $(X 5902=2)$ OR Highest grade completed $(X 5901)=12$ OR Highest grade completed (X5901)>12 \& No college degree (X5904=5) College graduate: Highest grade completed $(\mathrm{X} 5901)>12$ \& Has got a college degree $(\mathrm{X} 5904)=1$

Save for "rainy days": The survey question is "Now I'd like to ask a few questions about your (family's) savings. People have different reasons for saving. What are your (family's) most important reasons for saving?" The dummy refers to those reporting one of the following reasons: Emergencies; "rainy days"; other unexpected needs; for "security"/independence (X3006=25 or X3007=25).

Financial alertness: The survey question is "When making major decisions about borrowing and saving, some people shop around for the very best terms while others 
don't. What number would you be on the scale?" The 10-number scale ranges from 1"almost no shopping" to 10-"a great deal of shopping". Since 1995 the above question has been replaced by two separate ones - one for borrowing and one for saving - with responses coded on a 1 to 5 scale. We have standardized these measures by averaging the two questions asked in post 1995 surveys and express them in 1-10 scale. The dummy represents those declaring that they do a great deal of shopping (values 9, 10 in the scale).

Credit constrained: Indicates household response that it has been turned down for credit in the past five years or did not receive amount originally requested or did not apply for credit because it thought it might be turned down.

Willingness to take above average financial risk: The survey question is "Which of the following statements comes closest to the amount of financial risk that you and your (spouse/partner) are willing to take when you save or make investments?

1. take substantial financial risks expecting to earn substantial returns

2. take above average financial risks expecting to earn above average returns

3. take average financial risks expecting to earn average returns

4. not willing to take any financial risks"

The dummy represents those answering 1 or 2 . (X3014=1 or X3014=2).

Health poor: The survey question is "Would you say your health is excellent, good, fair, or poor?" Those describing their health as being poor are represented by the dummy $(\mathrm{X} 6030=4)$.

Bequest motive: Yes to "Do you expect to leave a sizable estate to others?" $(\mathrm{X} 5825=1)$.

Has received inheritance: Yes to "Have you ever received an inheritance, or been given substantial assets in a trust or in some other form?" (X5801=1).

Financial Institutions doing business with: "With how many financial institutions do you and your family living here currently have accounts or loans, or regularly do personal financial business? Include banks, savings and loans, credit unions, brokerages, loan companies, and so forth, but not institutions where you have only credit cards or business accounts" (X305).

Long investment horizon: The dummy represents those declaring that a period longer than 5 years is important when making their family's saving and spending plan (X3008) 
Table 1a: Stock Ownership Status in 1994 and 1999

\begin{tabular}{|c|c|c|}
\hline \multirow{2}{*}{1994} & \multicolumn{2}{|c|}{1999} \\
\cline { 2 - 3 } & Non-stock owner & Stock owner \\
\hline Non-stock owner & $\mathbf{4 2 . 9}$ & $\mathbf{1 7 . 8}$ \\
\hline Stock owner & $\mathbf{7 . 7}$ & $\mathbf{3 1 . 7}$ \\
\hline
\end{tabular}

Balanced PSID panel 1994,99,01,03 (families with no change in head). Family weights from 1999 are used. "Stock" refers to shares of stock in publicly held corporations, mutual funds, or investment trusts - including stocks in employer-based pensions or IRAs

Table 1b: Stock Ownership Status in 1999 and 2003

\begin{tabular}{|c|c|c|}
\hline \multirow{2}{*}{1999} & \multicolumn{2}{|c|}{2003} \\
\cline { 2 - 3 } & Non-stock owner & Stock owner \\
\hline Non-stock owner & $\mathbf{3 9 . 2}$ & $\mathbf{1 1 . 4}$ \\
\hline Stock owner & $\mathbf{9 . 9}$ & $\mathbf{3 9 . 4}$ \\
\hline
\end{tabular}

Balanced PSID panel 1994,99,01,03 (families with no change in head). Family weights from 1999 are used. "Stock" refers to shares of stock in publicly held corporations, mutual funds, or investment trusts - including stocks in employer-based pensions or IRAs 
Table 2: Bivariate Participation Probit, 1994-99

\begin{tabular}{|c|c|c|c|c|}
\hline & \multicolumn{2}{|c|}{ Own in 1994} & \multicolumn{2}{|c|}{ Own in 1999} \\
\hline & $\begin{array}{c}\text { Marginal } \\
\text { Effect }\end{array}$ & t-value & $\begin{array}{c}\text { Marginal } \\
\text { Effect }\end{array}$ & t-value \\
\hline Age $<35$ & -.1282 & 5.12 & -.0776 & 3.04 \\
\hline $35<$ Age $<49$ & -.0583 & 3.09 & -.0141 & 0.90 \\
\hline Age $>65$ & -.0126 & 0.27 & .0002 & 0.01 \\
\hline Married & .0282 & 1.01 & .0457 & 2.07 \\
\hline \# of children & -.0020 & 0.32 & -.0158 & 3.10 \\
\hline White & .1643 & 9.73 & .1772 & 17.00 \\
\hline Health poor/fair & -.0523 & 1.74 & -.0448 & 2.55 \\
\hline High school graduate & .1502 & 7.41 & .1635 & 8.99 \\
\hline College graduate & .3190 & 11.44 & .3412 & 19.59 \\
\hline Income & .0020 & 3.66 & .0026 & 4.36 \\
\hline non equity net Fin. Wealth & .0050 & 7.07 & .0092 & 9.85 \\
\hline net Real wealth & .0039 & 8.37 & .0047 & 4.15 \\
\hline Received inheritance last $5 \mathrm{yrs}$ & .1349 & 3.73 & .0856 & 4.63 \\
\hline Moved, 1994-99 & & & -.0008 & 0.07 \\
\hline$\hat{\rho}$ & \multicolumn{4}{|c|}{$.484($ s.e. .028) } \\
\hline Observations: 4,094 & \multicolumn{4}{|c|}{ log likelihood: -4138.6} \\
\hline
\end{tabular}

Balanced PSID panel 1994, 99 of families with no change in head and with non zero financial wealth in at least one of the two waves. Ownership regards shares of stock in publicly held corporations, mutual funds, or investment trusts -including stocks in employer-based pensions or IRAs. Variables refer to the year in question. Marginal effects, averaged across households (using 1999 family weights), refer to changes in the probabilities of owning stocks in each of the two waves caused by changes in regressors. The regression accounts also for gender and labor status. It controls for income, non equity net financial wealth and net real wealth by logarithms using the transformation $y=\ln (x)$ if $x \geq 1, y=-\ln (|x|)$ if $x \leq-1$ and $y=0$ if $-1<x<1$. The marginal effects for income, non equity financial wealth and net real wealth are based on a $\$ 1000$ increase in the underlying variables. Numbers in italics report absolute t-values, derived from simulated standard errors (details can be found in appendix A). 
Table 3: Bivariate Participation Probit, 1999-03

\begin{tabular}{|c|c|c|c|c|}
\hline & \multicolumn{2}{|c|}{ Own in 1999} & \multicolumn{2}{|c|}{ Own in 2003} \\
\hline & $\begin{array}{c}\text { Marginal } \\
\text { Effect }\end{array}$ & t-value & $\begin{array}{c}\text { Marginal } \\
\text { Effect }\end{array}$ & t-value \\
\hline Age $<35$ & -.0798 & 3.54 & -.0718 & 4.47 \\
\hline $35<$ Age $<49$ & -.0057 & 0.37 & -.0454 & 4.25 \\
\hline Age $>65$ & -.0143 & 0.83 & -.0214 & 1.26 \\
\hline Married & .0373 & 1.60 & .0481 & 1.96 \\
\hline \# of children & -.0212 & 3.64 & -.0235 & 3.23 \\
\hline White & .1761 & 15.23 & .1988 & 14.93 \\
\hline Health poor/fair & -.0177 & 0.97 & -.0624 & 3.25 \\
\hline High school graduate & .1723 & 8.71 & .1375 & 8.66 \\
\hline College graduate & .3423 & 19.67 & .3388 & 19.74 \\
\hline Income & .0028 & 6.62 & .0022 & 3.97 \\
\hline non equity net Fin. wealth & .0091 & 11.58 & .0113 & 10.89 \\
\hline net Real wealth & .0048 & 4.43 & .0032 & 2.86 \\
\hline Received inheritance last $5 \mathrm{yrs}$ & .0762 & 5.34 & .0541 & 1.56 \\
\hline Moved, 1999-03 & & & .0015 & 0.12 \\
\hline$\hat{\rho}$ & \multicolumn{4}{|c|}{$.553($ s.e. .026) } \\
\hline Observations: 4884 & \multicolumn{4}{|c|}{ log likelihood: -4684.2} \\
\hline
\end{tabular}

Balanced PSID panel 1999, 03 of families with no change in head and with non zero financial wealth in at least one of the two waves. Ownership regards shares of stock in publicly held corporations, mutual funds, or investment trusts -including stocks in employer-based pensions or IRAs. Variables refer to the year in question. Marginal effects, averaged across households (using 1999 family weights), refer to changes in the probabilities of owning stocks in each of the two waves caused by changes in regressors. The regression accounts also for gender and labor status. It controls for income, non equity net financial wealth and net real wealth by logarithms using the transformation $y=\ln (x)$ if $x \geq 1, y=-\ln (|x|)$ if $x \leq-1$ and $y=0$ if $-1<x<1$. The marginal effects for income, non equity financial wealth and net real wealth are based on a $\$ 1000$ increase in the underlying variables. Numbers in italics report absolute t-values, derived from simulated standard errors (details can be found in appendix A). 
Table 4: Selected Marginal Effects on the Probability to Exit from the Stock Market Conditional on Participation in the first period

\begin{tabular}{|l|c|c|c|c|}
\hline & \multicolumn{2}{|c|}{$1994-1999$} & \multicolumn{2}{c|}{$1999-2003$} \\
\hline & $\begin{array}{c}\text { Marginal } \\
\text { Effect }\end{array}$ & t-value & $\begin{array}{c}\text { Marginal } \\
\text { Effect }\end{array}$ & $t$-value \\
\hline & -.1225 & 7.73 & -.1455 & 9.40 \\
\hline White & .0261 & 1.53 & .0591 & 2.98 \\
\hline Health poor/fair & -.0013 & 2.71 & -.0020 & 3.73 \\
\hline Income & -.0053 & 10.07 & -.0066 & 10.28 \\
\hline $\begin{array}{l}\text { non equity net } \\
\text { Fin. wealth }\end{array}$ & -.0027 & 3.66 & -.0024 & 2.69 \\
\hline net Real wealth & & & & \\
\hline
\end{tabular}

Conditional marginal effects, averaged across households who own stocks in period one (using 1999 family weights), have been derived from the bivariate probit specifications presented in Tables 2 and 3 . They refer to changes in the conditional bivariate probabilities of not owning stocks in period two given ownership in period one, caused by changes in regressors. The marginal effects for income, non equity financial wealth and net real wealth are based on a $\$ 1000$ increase in the underlying variables in the second period. Numbers in italics report absolute t-values, derived from simulated standard errors (details can be found in the appendix). 
Table 5a: Stock Trading Inertia and Stock Trading Practices over Time

\begin{tabular}{|c|c|c|c|c|}
\hline period & No trade & Buy only & Sell only & Buy \& Sell \\
\hline $\mathbf{1 9 9 4 - 9 9}$ & 73.8 & 11.9 & 2.7 & 11.7 \\
\hline $\mathbf{1 9 9 9 - 0 3}$ & 71.9 & 11.7 & 3.5 & 12.9 \\
\hline $\mathbf{1 9 9 9 - 0 1}$ & 78.2 & 11.2 & 2.3 & 8.4 \\
\hline $\mathbf{2 0 0 1 - 0 3}$ & 82.3 & 7.0 & 3.5 & 7.3 \\
\hline
\end{tabular}

Balanced PSID panel 1994,99,01,03 (families with no change in head, 4,169 observations). Family weights from 1999 are used. "Stock" refers to shares of stock in publicly held corporations, mutual funds, or investment trusts - not including stocks in employer-based pensions or IRAs

Table 5b: Stock Trading Inertia by Education of Household Head

\begin{tabular}{|l|c|c|c|c|}
\hline & No trade 94-99 & No trade 99-03 & No trade 99-01 & No trade 01-03 \\
\hline Less than high school & 93.8 & 95.1 & 97.3 & 97.3 \\
\hline High school graduate & 80.2 & 78.1 & 83.3 & 87.7 \\
\hline College graduate & 53.4 & 51.0 & 60.9 & 66.1 \\
\hline
\end{tabular}

Balanced PSID panel 1994,99,01,03 (families with no change in head). Education refers to the beginning of each period. Family weights from 1999 are used. "Stock" refers to shares of stock in publicly held corporations, mutual funds, or investment trusts - not including stocks in employerbased pensions or IRAs

Table 5c: Stock Trading Inertia by Age of Household Head

\begin{tabular}{|l|c|c|c|c|}
\hline & No trade 94-99 & No trade 99-03 & No trade 99-01 & No trade 01-03 \\
\hline Age $<$ 35 & 78.0 & 79.4 & 83.9 & 88.6 \\
\hline $\mathbf{3 5 <}<$ Age $<$ 49 & 71.8 & 71.5 & 76.8 & 82.6 \\
\hline $\mathbf{4 9 <}<$ Age $<\mathbf{6 5}$ & 71.9 & 67.5 & 75.7 & 79.6 \\
\hline Age $>\mathbf{6 5}$ & 74.6 & 73.5 & 80.3 & 81.3 \\
\hline
\end{tabular}

Balanced PSID panel 1994,99,01,03 (families with no change in head). Age refers to the beginning of each period. Family weights from 1999 are used. "Stock" refers to shares of stock in publicly held corporations, mutual funds, or investment trusts - not including stocks in employer-based pensions or IRAs

Table 5d: Stock Trading Inertia by Non-equity Net Total Wealth

\begin{tabular}{|l|c|c|c|c|c|c|}
\hline $\begin{array}{l}\text { Non-equity Net } \\
\text { Total Wealth }\end{array}$ & \multicolumn{2}{|c|}{ No trade 94-99 } & \multicolumn{2}{c|}{ No trade 99-03 } & $\begin{array}{c}\text { No trade } \\
\mathbf{9 9 - 0 1}\end{array}$ & $\begin{array}{c}\text { No trade } \\
\mathbf{0 1 - 0 3}\end{array}$ \\
\hline $\mathbf{1}^{\text {st }}$ quartile & $(<\$ 11592)$ & 90.5 & $(<\$ 16742)$ & 92.5 & 93.9 & 96.1 \\
\hline $\mathbf{2}^{\text {nd }}$ quartile & $\begin{array}{c}(\$ 11592< \\
<\$ 62140)\end{array}$ & 78.9 & $\begin{array}{c}(\$ 16742< \\
<\$ 81852)\end{array}$ & 80.7 & 85.5 & 89.3 \\
\hline $\mathbf{3}^{\text {rd }}$ quartile & $\begin{array}{c}(\$ 62140< \\
<\$ 176861)\end{array}$ & 69.1 & $\begin{array}{c}(\$ 81852< \\
<\$ 212126)\end{array}$ & 65.2 & 74.6 & 77.9 \\
\hline $\mathbf{4}^{\text {th }}$ quartile & $(\$ 176861<)$ & 56.8 & $(\$ 212126<)$ & 49.3 & 58.9 & 65.8 \\
\hline
\end{tabular}

Balanced PSID panel 1994,99,01,03 (families with no change in head). Net wealth quartiles from the beginning of each period are considered. Family weights from 1999 are used. "Stock" refers to shares of stock in publicly held corporations, mutual funds, or investment trusts - not including stocks in employer-based pensions or IRAs. Amounts refer to \$2001 values. 
Table 6: Stock Trading Inertia and Stock Trading Practices over Time

\begin{tabular}{|c|c|c|c|c|}
\hline period & No trade & Buy only & Sell only & Buy \& Sell \\
\hline 1984-89* & 72.0 & 13.4 & 2.9 & 11.7 \\
\hline $1989-94 *$ & 70.2 & 18.0 & 1.7 & 10.0 \\
\hline 1994-99** & 72.4 & 12.3 & 2.7 & 12.5 \\
\hline 1999-03** & 70.0 & 12.7 & 3.8 & 13.4 \\
\hline 1999-01** & 77.2 & 11.9 & 2.3 & 8.7 \\
\hline $2001-03 * *$ & 80.7 & 7.5 & 3.9 & 7.8 \\
\hline
\end{tabular}

Balanced PSID panel 1989,94,99,01,03 (families with no change in head, 2,914 observations). Family weights from 1999 are used.

*Refers to shares of stock in publicly held corporations, mutual funds, or investment trusts including stocks in employer-based pensions or IRAs

**Refers to shares of stock in publicly held corporations, mutual funds, or investment trusts - not including stocks in employer-based pensions or IRAs 
Table 7: Multinomial Logit of Inertia in Trade and of Trading Practices: 1994-1999

\begin{tabular}{|c|c|c|c|c|c|c|c|c|c|c|}
\hline & \multicolumn{2}{|c|}{$\begin{array}{c}\text { No } \\
\text { involvement } \\
\text { with stocks }\end{array}$} & \multicolumn{2}{|c|}{$\begin{array}{l}\text { Involvement } \\
\text { with stocks, } \\
\text { but no trade }\end{array}$} & \multicolumn{2}{|c|}{ Buy only } & \multicolumn{2}{|c|}{ Sell only } & \multicolumn{2}{|c|}{ Buy \& Sell } \\
\hline & $\begin{array}{l}\text { Marginal } \\
\text { Effect }\end{array}$ & $\begin{array}{c}t- \\
\text { value }\end{array}$ & $\begin{array}{c}\text { Marginal } \\
\text { Effect }\end{array}$ & $\begin{array}{c}t- \\
\text { value }\end{array}$ & $\begin{array}{l}\text { Marginal } \\
\text { Effect }\end{array}$ & $\begin{array}{c}t- \\
\text { value }\end{array}$ & $\begin{array}{l}\text { Marginal } \\
\text { Effect }\end{array}$ & $\begin{array}{c}t- \\
\text { value }\end{array}$ & $\begin{array}{c}\text { Marginal } \\
\text { Effect }\end{array}$ & $\begin{array}{c}t- \\
\text { value }\end{array}$ \\
\hline Age $<35$ & .0616 & 2.37 & -.1107 & 4.03 & .0467 & 2.30 & -.0321 & 3.10 & .0345 & 1.78 \\
\hline $35<$ Age $<49$ & .0344 & 1.45 & -.0647 & 2.56 & .0346 & 2.09 & -.0251 & 2.45 & .0208 & 1.29 \\
\hline Age $>65$ & -.0028 & 0.09 & -.0174 & 0.49 & -.0087 & 0.40 & .0049 & 0.28 & .0239 & 1.00 \\
\hline Married & -.0251 & 1.10 & .0382 & 1.57 & .0220 & 1.36 & -.0022 & 0.24 & -.0328 & 1.90 \\
\hline \# of children & .0160 & 2.30 & .0093 & 1.25 & -.0141 & 2.81 & -.0011 & 0.39 & -.0101 & 1.78 \\
\hline White & -.1950 & 10.86 & .0512 & 2.90 & .0521 & 4.59 & .0229 & 3.83 & .0689 & 6.33 \\
\hline Health poor/fair & .0724 & 2.90 & -.0325 & 1.25 & -.0041 & 0.19 & .0070 & 0.60 & -.0428 & 2.27 \\
\hline $\begin{array}{l}\text { Health gets } \\
\text { worse, 1994-99 }\end{array}$ & .0346 & 1.28 & .0167 & 0.55 & -.0309 & 1.50 & -.0061 & 0.53 & -.0143 & 0.63 \\
\hline $\begin{array}{l}\text { High school } \\
\text { graduate }\end{array}$ & -.1806 & 6.99 & .0940 & 3.82 & .0611 & 3.74 & .0024 & 0.22 & .0230 & 1.37 \\
\hline College graduate & -.3549 & 11.89 & .1196 & 4.12 & .0992 & 5.14 & .0106 & 0.82 & .1256 & 6.08 \\
\hline $\begin{array}{l}\text { Become retired, } \\
1994-99\end{array}$ & -.0091 & 0.27 & -.0612 & 1.79 & .0077 & 0.27 & .0118 & 0.72 & .0509 & 1.65 \\
\hline Income & -.0037 & 4.84 & .0012 & 1.84 & .0010 & 4.88 & .0002 & 1.63 & .0013 & 4.60 \\
\hline $\begin{array}{l}\text { non equity net } \\
\text { Fin. Wealth }\end{array}$ & -.0063 & 6.96 & .0030 & 3.60 & .0022 & 4.38 & -.0002 & 0.77 & .0014 & 3.28 \\
\hline net Real wealth & -.0039 & 3.37 & .0028 & 3.04 & .0006 & 1.24 & .0000 & 0.03 & .0004 & 0.80 \\
\hline $\begin{array}{l}\text { Received inheritance, } \\
1989-94\end{array}$ & -.1272 & 4.03 & .0576 & 1.70 & -.0103 & 0.54 & .0144 & 0.97 & .0656 & 3.02 \\
\hline $\begin{array}{l}\text { Received inheritance, } \\
\text { 1994-99 }\end{array}$ & -.1056 & 3.94 & -.0455 & 1.77 & .0670 & 3.32 & .0007 & 0.06 & .0834 & 4.41 \\
\hline Moved, 1994-99 & .0242 & 1.62 & -.0255 & 1.59 & -.0076 & 0.69 & .0024 & 0.33 & .0065 & 0.59 \\
\hline
\end{tabular}

Balanced PSID panel 1994,99 of families with no change in head and with non zero financial wealth in at least one of the two waves. Trading regards shares of stock in publicly held corporations, mutual funds, or investment trusts - not including stocks in employer-based pensions or IRAs. Marginal effects, averaged across households (using 1999 family weights), refer to changes in the probability of an event's occurrence caused by changes in regressors. The regression accounts also for gender and labor status. It controls for income, non equity net financial wealth and net real wealth by logarithms using the transformation $y=\ln (x)$ if $x \geq 1, y=-\ln (|x|)$ if $x \leq-1$ and $y=0$ if $-1<x<1$. The marginal effects for income, non equity financial wealth and net real wealth are based on a $\$ 1000$ increase in the underlying variables and for children on the presence of an additional child. Numbers in italics report absolute t-values, derived from simulated standard errors (details can be found in appendix A). 
Table 8: Multinomial Logit of Inertia in Trade and of Trading Practices: 1999-2003

\begin{tabular}{|c|c|c|c|c|c|c|c|c|c|c|}
\hline & \multicolumn{2}{|c|}{$\begin{array}{l}\text { No involvement } \\
\text { with stocks }\end{array}$} & \multicolumn{2}{|c|}{$\begin{array}{c}\text { Involvement } \\
\text { with stocks, but } \\
\text { no trade } \\
\end{array}$} & \multicolumn{2}{|c|}{ Buy only } & \multicolumn{2}{|c|}{ Sell only } & \multicolumn{2}{|c|}{ Buy \& Sell } \\
\hline & $\begin{array}{l}\text { Marginal } \\
\text { Effect }\end{array}$ & $\begin{array}{c}t- \\
\text { value }\end{array}$ & $\begin{array}{c}\text { Marginal } \\
\text { Effect }\end{array}$ & $\begin{array}{c}t- \\
\text { value }\end{array}$ & $\begin{array}{c}\text { Marginal } \\
\text { Effect }\end{array}$ & t-value & $\begin{array}{c}\text { Marginal } \\
\text { Effect }\end{array}$ & $\begin{array}{c}t- \\
\text { value }\end{array}$ & $\begin{array}{c}\text { Marginal } \\
\text { Effect }\end{array}$ & t-value \\
\hline Age $<35$ & .0746 & 3.35 & -.1043 & 4.54 & .0120 & 0.71 & .0011 & 0.09 & .0166 & 1.02 \\
\hline $35<$ Age $<49$ & .0450 & 2.38 & -.0634 & 3.04 & .0212 & 1.47 & .0060 & 0.60 & $\begin{array}{r}- \\
.0088 \\
\end{array}$ & 0.69 \\
\hline Age $>65$ & .0371 & 1.40 & -.0330 & 1.00 & -.0238 & 1.24 & -.0050 & 0.40 & .0247 & 1.03 \\
\hline Married & -.0301 & 1.44 & .0386 & 1.69 & .0113 & 0.76 & .0283 & 2.49 & $.0480^{-}$ & 3.24 \\
\hline \# of children & .0214 & 3.49 & .0013 & 0.18 & -.0065 & 1.34 & -.0027 & 0.88 & .0136 & 2.67 \\
\hline White & -.1787 & 11.88 & .0625 & 3.87 & .0345 & 3.32 & .0184 & 2.83 & .0633 & 6.09 \\
\hline Health poor/fair & .0661 & 3.24 & -.0258 & 1.06 & -.0081 & 0.42 & -.0141 & 1.51 & $.0182^{-}$ & 1.00 \\
\hline $\begin{array}{l}\text { Health gets worse } \\
1999-01\end{array}$ & .0526 & 2.15 & -.0313 & 1.04 & -.0089 & 0.41 & -.0193 & 1.56 & .0068 & 0.27 \\
\hline $\begin{array}{l}\text { Health gets worse } \\
2001-03\end{array}$ & .0606 & 2.45 & -.0136 & 0.46 & -.0173 & 0.77 & -.0027 & 0.18 & $\begin{array}{r}- \\
.0270 \\
\end{array}$ & 1.22 \\
\hline $\begin{array}{l}\begin{array}{l}\text { High school } \\
\text { graduate }\end{array} \\
\end{array}$ & -.1680 & 7.14 & .0475 & 2.00 & .0611 & 4.24 & .0186 & 2.21 & .0408 & 2.76 \\
\hline College graduate & -.3240 & 11.58 & .0363 & 1.32 & .0944 & 5.41 & .0401 & 3.89 & .1533 & 8.73 \\
\hline $\begin{array}{l}\text { Become retired, } \\
\text { 1999-01 }\end{array}$ & -.0317 & 0.90 & -.0256 & 0.68 & -.0161 & 0.65 & .0267 & 1.18 & .0467 & 1.60 \\
\hline $\begin{array}{l}\text { Become retired, } \\
2001-03\end{array}$ & .1129 & 3.09 & -.1002 & 2.67 & .0123 & 0.40 & -.0066 & 0.35 & $\begin{array}{r}- \\
.0184 \\
\end{array}$ & 0.75 \\
\hline Income & -.0033 & 4.23 & .0015 & 2.59 & .0006 & 2.26 & -.0001 & 0.17 & .0013 & 10.30 \\
\hline $\begin{array}{l}\text { non equity net } \\
\text { Fin. Wealth }\end{array}$ & -.0089 & 9.62 & .0055 & 6.35 & .0018 & 3.84 & .0002 & 0.57 & .0014 & 4.55 \\
\hline net Real wealth & -.0054 & 4.66 & .0018 & 1.71 & .0019 & 4.10 & .0003 & 0.65 & .0014 & 3.00 \\
\hline $\begin{array}{l}\text { Received inheritance } \\
1994-99\end{array}$ & -.0489 & 2.00 & -.0561 & 2.24 & .0001 & 0.01 & .0277 & 2.22 & .0772 & 4.56 \\
\hline $\begin{array}{l}\text { Received inheritance } \\
1998-03\end{array}$ & -.0473 & 1.44 & -.0319 & 0.94 & .0066 & 0.30 & .0350 & 1.94 & .0347 & 1.85 \\
\hline Moved, 1999-01 & -.0032 & 0.20 & -.0410 & 2.35 & .0085 & 0.67 & .0149 & 1.62 & .0208 & 1.56 \\
\hline Moved, 2001-03 & .0080 & 0.56 & -.0218 & 1.27 & .0079 & 0.65 & .0003 & 0.03 & .0057 & 0.45 \\
\hline Observati & ons: 4,976 & & & & $\log \mathrm{li}$ & hood: & 41.9 & & & \\
\hline
\end{tabular}

Balanced PSID panel 1999, 01 and 03 of families with no change in head and with non zero financial wealth in at least one of the three waves. Trading regards shares of stock in publicly held corporations, mutual funds, or investment trusts - not including stocks in employer-based pensions or IRAs. Marginal effects, averaged across households (using 1999 family weights), refer to changes in the probability of an event's occurrence caused by changes in regressors. The regression accounts also for gender and labor status. It controls for income, non equity net financial wealth and net real wealth by logarithms using the transformation $y=\ln (x)$ if $x \geq 1, y=-\ln (|x|)$ if $x \leq-1$ and $y=0$ if $-1<x<1$. The marginal effects for income, non equity financial wealth and net real wealth are based on a $\$ 1000$ increase in the underlying variables. Numbers in italics report absolute t-values, derived from simulated standard errors (details can be found in appendix A). 
Table 9: Trading in the Population and Among Owners of Brokerage Accounts

\begin{tabular}{|c|c|c|c|c|}
\hline Period & $\begin{array}{c}\text { Stock ownership } \\
\text { rates * }\end{array}$ & $\begin{array}{c}\text { Brokerage } \\
\text { account } * *\end{array}$ & $\begin{array}{c}\text { Stock trading } \\
\text { rates *** }\end{array}$ & $\begin{array}{c}\text { Stock trading rates } \\
\text { among brokerage } \\
\text { account owners }\end{array}$ \\
\hline $1988-89$ & $16.9 \%$ & $9.4 \%$ & $6.8 \%$ & $72.0 \%$ \\
\hline $1991-92$ & $17.0 \%$ & $12.5 \%$ & $8.6 \%$ & $69.0 \%$ \\
\hline $1994-95$ & $15.3 \%$ & $12.1 \%$ & $8.3 \%$ & $68.3 \%$ \\
\hline $1997-98$ & $19.2 \%$ & $15.5 \%$ & $11.8 \%$ & $76.2 \%$ \\
\hline $2000-01$ & $21.3 \%$ & $18.2 \%$ & $13.5 \%$ & $74.3 \%$ \\
\hline $2003-04$ & $20.7 \%$ & $15.8 \%$ & $10.4 \%$ & $65.4 \%$ \\
\hline
\end{tabular}

SCF 1989,92,95,98,01,04 weighted data. The reported statistics are corrected for multiple imputation. * \% of households with directly held equity

** $\%$ of households with a brokerage account for the purchase or sale of stocks and other securities $* * * \%$ of households that bought or sold stocks or other securities through a broker 
Table 10: Probit model (with selection) of the Probability of Trading Stocks through Brokerage Accounts

\begin{tabular}{|c|c|c|c|c|}
\hline & $\begin{array}{r}\operatorname{Pr}(\mathrm{Brc} \\
\text { Acc }\end{array}$ & $\begin{array}{l}\text { erage } \\
\text { int) }\end{array}$ & $\operatorname{Pr}(\operatorname{Tr}$ & ding) \\
\hline & $\begin{array}{c}\text { Marginal } \\
\text { Effect }\end{array}$ & t-value & $\begin{array}{c}\text { Marginal } \\
\text { Effect }\end{array}$ & $t$-value \\
\hline Age & .0012 & 6.32 & .0013 & 2.36 \\
\hline Male & .0271 & 4.23 & .0380 & 1.51 \\
\hline Married & -.0166 & -2.73 & .0154 & 0.77 \\
\hline Has children & -.0203 & -4.65 & -.0119 & -0.86 \\
\hline White & .0510 & 8.87 & .0396 & 1.59 \\
\hline Health poor & -.0397 & -3.82 & -.0110 & -0.24 \\
\hline High school graduate & .0581 & 8.89 & .0321 & 0.76 \\
\hline College graduate & .1406 & 19.49 & .0970 & 2.27 \\
\hline Save for "rainy days" & -.0016 & -0.40 & -.0181 & -1.41 \\
\hline Financial alertness & .0036 & 0.78 & -.0080 & -0.56 \\
\hline Non-investment Income & .0005 & 5.04 & .0004 & 0.83 \\
\hline non equity net Financial Wealth & .0016 & 16.96 & .0004 & 2.60 \\
\hline net Real Wealth & .0017 & 24.18 & .0010 & 2.06 \\
\hline Bequest motive & .0531 & 11.69 & .0444 & 3.71 \\
\hline Has received inheritance & .0254 & 5.77 & -.0053 & -0.41 \\
\hline Credit constrained & -.0309 & -4.59 & -.0021 & -0.09 \\
\hline Willingness to take above average financial risk & .0676 & 14.09 & .0582 & 4.98 \\
\hline Long investment horizon & .0228 & 5.63 & .0232 & 1.92 \\
\hline Financial institutions doing business with: 2 & .0561 & 10.40 & .0434 & 1.60 \\
\hline Financial institutions doing business with: 3 & .0995 & 16.14 & .0488 & 1.89 \\
\hline Financial institutions doing business with: $4 / 5$ & .1499 & 21.81 & .0719 & 2.76 \\
\hline Financial institutions doing business with: $6+$ & .2203 & 21.55 & .0855 & 3.16 \\
\hline Year 1992 & .0265 & 5.24 & - & - \\
\hline Year 1995 & .0356 & 5.72 & - & - \\
\hline Year 1998 & .0398 & 6.15 & - & - \\
\hline Year 2001 & .0683 & 10.77 & - & - \\
\hline Year 2004 & .0512 & 9.21 & - & - \\
\hline$+1 \%$ in $S \& P 500$ real growth rate $(>0)$ & - & - & .0089 & 5.05 \\
\hline$+1 \%$ in $\mathrm{S} \& \mathrm{P} 500$ real growth rate $(<0)$ & - & - & -.0148 & -4.50 \\
\hline$\hat{\rho}$ & & .99 & $.0034)$ & \\
\hline Observations: 24,614 & & g likelih & $\mathrm{d}:-12,089.6$ & \\
\hline
\end{tabular}

Pooled data from 1989,92,95,98,01,04 SCFs. Two-stage probit regression, correcting for selectivity bias among brokerage account owners. The specification accounts for age through a $2^{\text {nd }}$ order polynomial, and for labor status. It controls for logarithms of income, non equity net financial wealth and net real wealth using $y=\ln (x)$ if $\mathrm{x} \geq 1, \mathrm{y}=-\ln (|\mathrm{x}|)$ if $\mathrm{x} \leq-1$ and $\mathrm{y}=0$ if $-1<\mathrm{x}<1$. "S\&P500 real growth rates" (in the year preceding the interview), an interaction term with years showing a negative rate (1995 and 2001), and a dummy representing these years are included in the second stage to allow for asymmetric effects between periods of positive and negative rates. Marginal effects are averaged across households (using survey weights). The marginal effects for income, non equity financial wealth and net real wealth are based on a $\$ 1000$ increase in the underlying variables and for age on a one year increase. Marginal effects in the second stage are calculated conditional on brokerage account ownership. For S\&P500 real growth rate they show the effects on the probability of trading caused by a $1 \%$ increase in the S\&P500 real growth rate during expansions and contractions. Numbers in italics report absolute t-values, derived from simulated standard errors (details can be found in appendix A). Reported estimates are corrected for multiple imputation. 
Figure 1: Conditional Probabilities of Stock Ownership: Effects of Income and Wealth
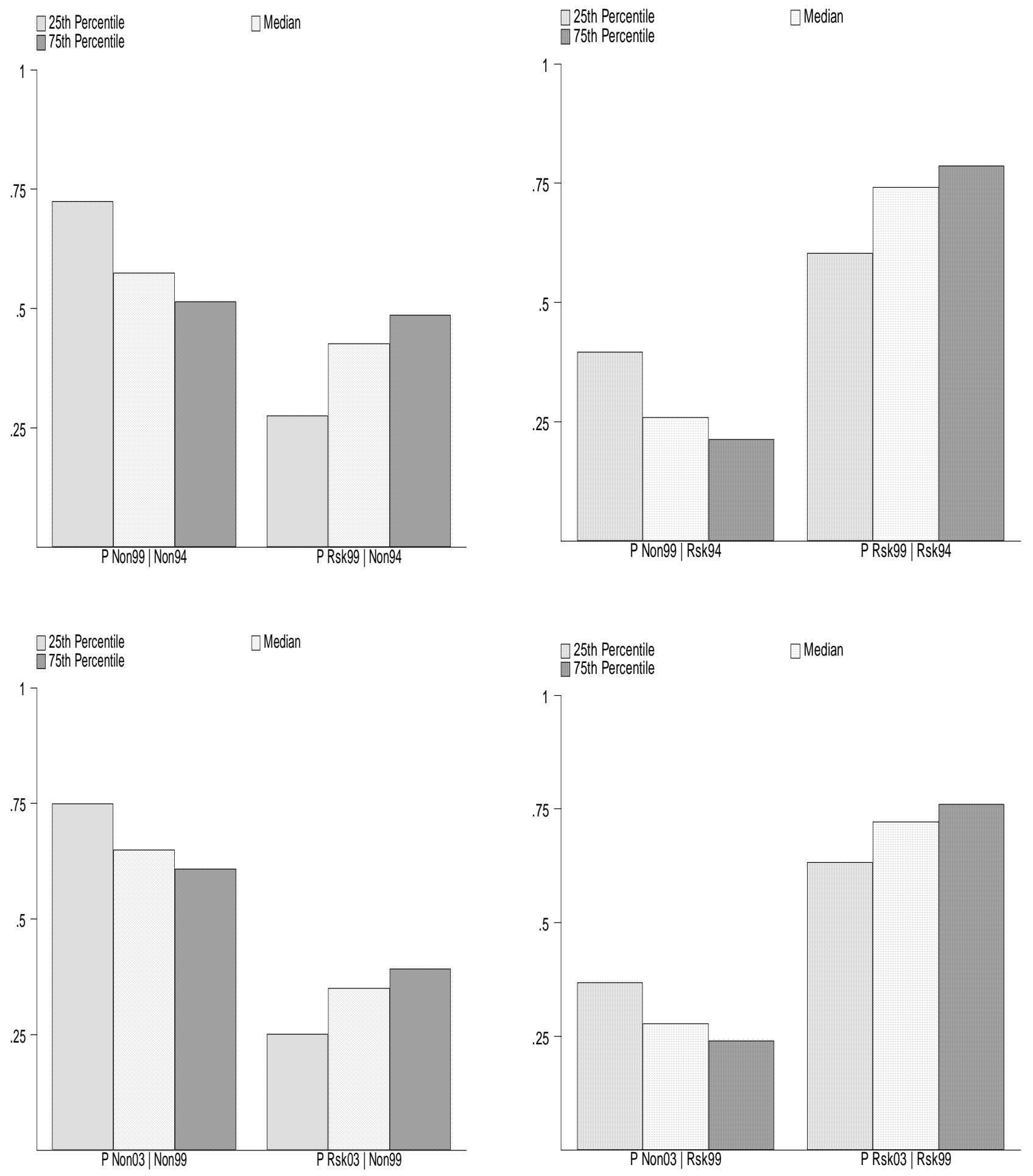
Figure 2: Conditional Probabilities of Stock Ownership: The effect of Education
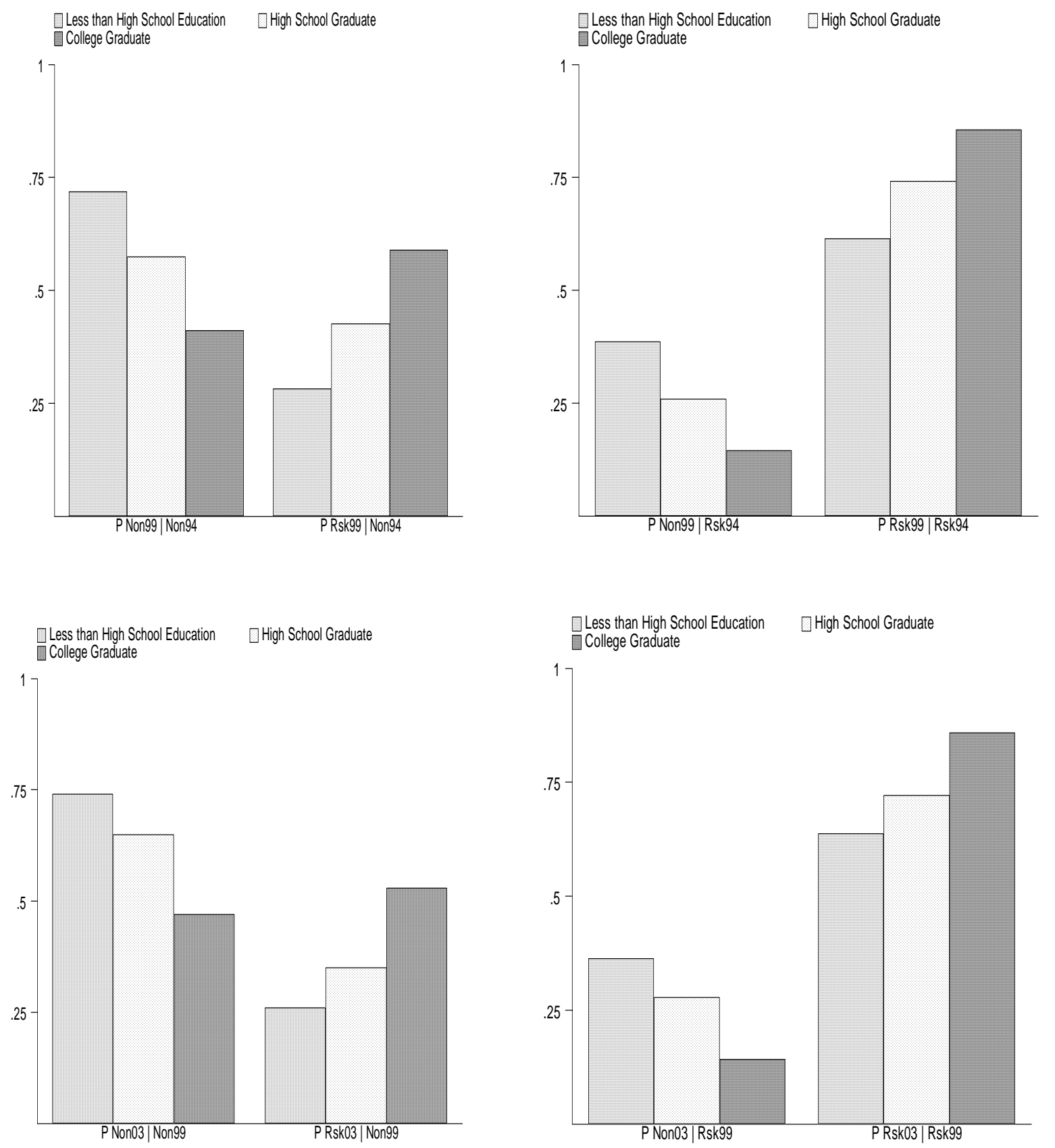


\section{Endnotes}

${ }^{1}$ Campbell (2006) argues that households make investment mistakes with respect to (non)participation, (under)diversification, and debt refinancing. Calvet, Campbell, Sodini (2005) find, using Swedish data, that mistakes are disproportionately present among groups of lower education and resources. Poor understanding of investment options has been linked to lack of international diversification (Graham, Harvey, Huang, 2005) and to poor planning for retirement (Lusardi and Mitchell, 2005).

${ }^{2}$ Grinblatt and Keloharju (2001) use data from the central register of shareholdings for Finnish stocks in the Finnish Central Securities Depository that cover all stock market participants (individuals and institutions) but obviously not individuals that are not stockholders. They employ Logit regressions to identify the determinants of buying and selling activity of individuals and institutions over a two-year period, and they find evidence that investors are reluctant to realize losses, that they engage in tax-loss selling activity, and that past returns and historical price patterns affect trading.

${ }^{3}$ Just under 90 percent made zero or one change in accumulated assets, while more than two thirds made zero or one change in their flow allocations.

${ }^{4}$ This is in line also with Sirri and Tufano (1998), who find a similar asymmetry for mutual fund flows: mutual fund consumers chase returns, flocking to funds with the highest recent returns, though failing to flee from poor performers.

${ }^{5}$ Milgrom and Stokey showed that, under rational expectations and regardless of the institutional structure, if the initial allocation is ex ante Pareto-optimal, then receiving private information cannot create incentives to trade. This is because, under Pareto optimality, the trader only hopes to find an advantageous bet, but the mere willingness of the other traders to accept their parts of the bet convinces at least one trader that his own part is unfavorable. Common knowledge that the trade is both feasible and acceptable to all traders is a crucial assumption for this result.

${ }^{6}$ See, for example, Haliassos and Bertaut (1995), Heaton and Lucas (2000), Gollier (2001), Viceira (2001), Campbell and Viceira (2002), Haliassos and Michaelides (2003), Cocco, Gomes and Maenhout (2005), and Gomes and Michaelides (2005).

${ }^{7}$ For empirical estimates of thresholds to fixed entry costs, see Vissing Jorgensen (2002) and Paiella (2004).

${ }^{8}$ See, for example, Laibson et al. (2003).

9 An early empirical study that documented such exits using a panel subsample of the SCF in the 1980s, was Bertaut (1998).

${ }^{10}$ Barber and Odean (2000) found using their discount broker accounts data that the frequency of trading was lower in IRA accounts than in taxable accounts, and that liquidity shocks were more likely to induce trading in mutual funds than in directly held stocks. They conjecture that the former finding is due either to tax-motivations or to more limited willingness of households to trade speculatively on their retirement accumulation because they associate it with future safety. The latter may be due to lower transactions costs associated with mutual fund trades.

${ }^{11}$ In regressions where endogeneity bias may be an issue, our net financial wealth measure does not include the value of stocks.

${ }^{12}$ All money values have been deflated using the CPI-U index and expressed into constant 2001 prices.

${ }^{13}$ Survey collection issues include the following. First, the data center merges families with the same head, but it is conceivable that the head is the same but the family is different. Second, prior to 1999 the question about stocks included stocks in IRAs, but in 1999 the question was split in two, separating IRAs from stocks in individual accounts and mutual funds. It is possible that some respondents' answers to the stock ownership question were affected by this change, especially if they were used to the old question sequence. Third, the 2001 interview was the first where active saving questions refer to a two- rather than four-year period, and some errors might be due to this change. Fourth, some respondents may be thinking not in terms of the interval between interviews but in terms of calendar years. We are grateful to Ms. Donna Nordquist of the PSID for bringing these issues to our attention.

${ }_{14}$ This latter observation is consistent with the finding from SCF data that overall stockholding participation rates were slightly higher in 2001 than in 1998.

${ }_{15}$ When we use SCF data below, we are able to study frequency of trading stocks directly for households with brokerage accounts.

${ }^{16}$ This is not costless, as the requirement for a balanced panel lowers the number of observations from more than 4,000 to slightly less than 3,000 .

${ }^{17}$ The only exception seems to be the increase in the proportion of households buying only under the broader definition of stockholding in the period 1989-94, presumably due to the sizeable entry of households into retirement accounts. 
${ }^{18}$ We use LR tests to see whether any of the categories we consider is statistically indistinguishable from another. For all possible pairs, we reject the null that a given pair of outcomes is indistinguishable. This reflects the distinct roles that variables in the model play for each of the options considered.

19 All characteristics refer to the first period. We exclude households with zero financial wealth holdings at both endpoints of 1994-99, and those with zero financial wealth in all three waves 19992001-2003. The latter choice explains the somewhat higher number of observations in the model of Table 7 compared to Table 3 . Hausman tests failed to reject the IIA assumption for both models estimated over the periods 1994-99 and 1999-2003.

${ }^{20}$ We also consider changes of address (moves) during the period in question, which could be associated with asset rebalancing. Controlling for other changes that have already been mentioned, geographical moves do not appear to have significant effects on stock trading behavior before or after the downswing.

21 Specifically, they took the following values: $+.07(12 / 1987-12 / 1988),+.23(12 / 1990-12 / 1991)$, $-.04(12 / 1993-12 / 1994),+.29(12 / 1996-12 / 1997),-.13(12 / 1999-12 / 2001),+.24(12 / 2002-12 / 2003)$.

${ }^{22}$ Interaction terms for household characteristics did not turn out to be statistically significant, implying identical effects of characteristics on the incidence of trading through brokerage accounts across upswings and downswings, and they were not included in the final specification.

${ }^{23}$ There is growing discussion of these issues and an effort to provide codes that circumvent some inefficiencies of standard software packages (see, for instance, King et al., 2003; and Bartus, 2005). Brambor et al. (2005) discuss models with interactions and point to problems in empirical literature. We follow their notion in calculating the effect of the interacted S\&P500 real growth rate. 


\section{CFS Working Paper Series:}

\begin{tabular}{|c|c|c|}
\hline No. & Author(s) & Title \\
\hline 2006/14 & $\begin{array}{l}\text { Yanis Bilias, } \\
\text { Dimitris Georgarakos } \\
\text { Michael Haliassos }\end{array}$ & Portfolio Inertia and Stock Market Fluctuations \\
\hline $2006 / 13$ & $\begin{array}{l}\text { Lars Jonung } \\
\text { Ludger Schuknecht } \\
\text { Mika Tujula }\end{array}$ & $\begin{array}{l}\text { The Boom-Bust Cycle in Finland and Sweden } \\
\text { 1984-1995 in an International Perspective }\end{array}$ \\
\hline $2006 / 12$ & $\begin{array}{l}\text { Julia Hirsch } \\
\text { Uwe Walz }\end{array}$ & $\begin{array}{l}\text { Why Do Contracts Differ between VC Types? } \\
\text { Market Segmentation versus Corporate } \\
\text { Governance Varieties }\end{array}$ \\
\hline 2006/11 & $\begin{array}{l}\text { Carsten Bienz } \\
\text { Julia Hirsch }\end{array}$ & The Dynamics of Venture Capital Contracts \\
\hline 2006/10 & $\begin{array}{l}\text { Renata Bottazzi } \\
\text { Tullio Jappelli } \\
\text { Mario Padula }\end{array}$ & $\begin{array}{l}\text { Retirement Expectations, Pension Reforms, and } \\
\text { Their Impact on Private Wealth Accumulation }\end{array}$ \\
\hline 2006/09 & $\begin{array}{l}\text { Markus Haas } \\
\text { Stefan Mittnik } \\
\text { Marc S. Paolella }\end{array}$ & Multivariate Normal Mixture GARCH \\
\hline 2006/08 & $\begin{array}{l}\text { Elena Carletti } \\
\text { Philipp Hartmann } \\
\text { Giancarlo Spagnolo }\end{array}$ & Bank Mergers, Competition and Liquidity \\
\hline 2006/07 & $\begin{array}{l}\text { Alexander Muermann } \\
\text { Stephen H. Shore }\end{array}$ & $\begin{array}{l}\text { Strategic Trading and Manipulation with Spot } \\
\text { Market Power }\end{array}$ \\
\hline 2006/06 & $\begin{array}{l}\text { Jan Pieter Krahnen } \\
\text { Frank A. Schmid } \\
\text { Erik Theissen }\end{array}$ & $\begin{array}{l}\text { Investment Performance and Market Share: A } \\
\text { Study of the German Mutual Fund Industry }\end{array}$ \\
\hline 2006/05 & Jan Pieter Krahnen & $\begin{array}{l}\text { Die Stabilität von Finanzmärkten: Wie kann die } \\
\text { Wirtschaftspolitik Vertrauen schaffen? }\end{array}$ \\
\hline 2006/04 & $\begin{array}{l}\text { Jan Pieter Krahnen } \\
\text { Christian Wilde }\end{array}$ & $\begin{array}{l}\text { Risk Transfer with CDOs and Systemic Risk in } \\
\text { Banking }\end{array}$ \\
\hline
\end{tabular}

Copies of working papers can be downloaded at http://www.ifk-cfs.de 